\title{
Legal Rational Myths: The New Institutionalism and the Law and Society Tradition
}

\author{
Mark C. Suchman and Lauren B. Edelman
}

Walter W. Powell \& Paul J. DiMaggio, eds. The New Institutionalism in Organizational Analysis. Chicago: University of Chicago Press, 1991.

Recent years have witnessed the early stages of a convergence between the sociology of law and the sociology of organizations. Contemporary sociolegal scholarship increasingly recognizes that important aspects of legal life occur within bureaucratic settings, such as law firms, regulatory agencies and corporations. ${ }^{1}$ Simultaneously, contemporary organizations theory increasingly acknowledges that important aspects of organizational activity occur within legal environments, such as rights regimes, disputing cultures, and regulatory systems. ${ }^{2}$ Although few researchers have explicitly attempted

Mark C. Suchman is an assistant professor of sociology and law, University of Wisconsin-Madison. Lauren B. Edelman is professor of law and sociology, University of Calfornia-Berkeley. Authorship of this article was fully collaborative.

1. See, e.g., Robert Nelson, Partners with Power: Social Transformation of the Large Law Firm (Berkeley: University of California Press, 1989); Marc Galanter \& Thomas M. Palay, Toumament of Lauryers: The Transformation of the Big Law Firm (Chicago: University of Chicago Press, 1991); Wolf Heydebrand \& Carroll Seron, Rationalizing Justice: The Political Economy of Federal District Courts (Albany, N.Y.: State University of New York Press, 1990); Alfred Blumrosen, Modern Law: The Transmission System and Equal Employment Opportunity (Madison: University of Wisconsin Press, 1993) ("Blumrosen, Modern Law").

2. See, e.g., Oliver E. Williamson, "Transaction-Cost Economics: The Governance of Contractual Relations," 22 J.L. \& Econ. 233-61 (1979); Mark C. Suchman \& Mia L. Cahill, "The Hired-Gun as Conciliator: The Case of Lawyers in Silicon Valley" (presented at University of Wisconsin Institute of Legal Studies Conference on Business Disputing, Madison, 1993); James N. Baron, Frank R. Dobbin, \& P. Devereaux Jennings, "War and Peace: The Evolution of Modern Personnel Administration in U.S. Industry," 92 Am. J. Soc. 350 (1986); Frank R. Dobbin, Lauren Edelman, John W. Meyer, W. Richard Scott, \& Ann Swidler, "The Expansion of Due Process in Organizations," in Lynne G. Zucker, ed., Institutional Patterns in Organizations: Culture and Environment (Cambridge, Mass: Ballinger, 1988) ("Dobbin et al., 'Expansion of Due Process"'); Lauren B. Edelman, "Legal Environments and Organizational 
to integrate these two fields, ${ }^{3}$ the opportunities for rapprochement are becoming increasingly apparent. Nowhere are the problems and the promises of synthesis clearer than in the collection of organizational theories that go by the name of "New Institutionalism."

The 1991 publication of Powell and DiMaggio's anthology, The New Institutionalism in Organizational Analysis, ${ }^{4}$ creates a particularly accessible path into organizational institutionalism for researchers whose backgrounds lie primarily in the sociolegal realm. Here, in a single volume, two of organizational sociology's foremost institutional thinkers collect not only the foundational articles of this tradition but also a broad sample of more recent pieces that ably illustrate the school's empirical predilections and theoretical problematics. The anthology begins with an expansive introductory essay by DiMaggio and Powell, contrasting the new institutionalism in organizational sociology both against other "new institutionalisms" in economics and political science, and also against older institutional traditions in sociology itself. Following this introduction, the book reproduces four of the foundational works in organizational institutionalism, all of which originally appeared between 1977 and 1983. The next section shifts from retrospection to innovation, presenting five sweeping theoretical essays by leading institutional scholars, each laying out a distinctive vision of the field's unresolved issues and future directions. Finally, part 3 offers six previously unpublished empirical investigations, on topics ranging from art museums to corporate philanthropy to higher education to social service delivery to industrial structure in the United States and Asia.

Sociolegal researchers will find much to like in this compendium and in the intellectual perspective that it reflects: The New Institutionalism in organizational analysis takes rule systems seriously; it acknowledges and even exalts the causal force of normative beliefs; and it thoroughly embraces the kinds of cognitive and constitutive effects that play an increasingly large role in sociolegal theory. ${ }^{5}$ Moreover, its insights into the behavior of individuals, organizations and societies can deepen and enrich existing

Governance: The Expansion of Due Process in the Workplace," 95 Am. J. Soc. 1401 (1990); id., "Legal Ambiguity and Symbolic Structures: Organizational Mediation of Civil Rights Law," 97 Am. J. Soc. 1531 (1992); Neil Fligstein, The Transformation of Corporate Control (Cambridge: Harvard University Press, 1990) ("Fligstein, Transformation").

3. But see Andrew L. Creighton, "The Emergence of Incorporation as a Legal Form for Organizations" (Ph.D. diss., Dep't of Sociology, Stanford University, 1990) ("Creighton, 'Emergence"); Edelman, 95 Am. J. Soc. and 97 Am. J. Soc.; Mark C. Suchman, "On Advice of Counsel: Law Firms and Venture Capital Funds as Information Intermediaries in the Structuration of Silicon Valley" (Ph.D. diss., Dep't of Sociology, Stanford University, 1994) ("Suchman, 'On Advice of Counsel"').

4. Contributions from Powell \& DiMaggio, eds., The New Institutionalism in Organizational Analysis are cited to "New Institutionalism" by author(s) and title and, on repeated citation, by short title.

5. E.g., Mark Tushnet, "An Essay on Rights," 62 Tex. L. Rev. 1363 (1984); Peter Gabel, "Reification in Legal Reasoning," 3 Res. L. \& Soc. 25 (1980). 
treatments of related subjects in the legal realm. In short, the New Institutionalism presents a view of organizational life that fits quite nicely with the central concerns of contemporary sociology of law.

At the same time, however, many who draw their inspiration from the Law and Society tradition may be disconcerted by the image of law itself within organizational institutionalism. In arguing for the importance of rule structures in organizational life, institutional theorists often go a bit too far, embracing a model of the law that verges on naive Legal Formalism. To many organizational theorists, it seems, the law (and, by extension, the state) represents a distinctively explicit, authoritative, and coercive exogenous constraint on organizational behavior. The legal environment depicted by institutional theory is, largely, an environment of "law-on-the-books": Rules are clear, enforcement is firm, and legal effects are substantive. The ambiguity, the politicization, and the symbolism of the "law-in-action" tend to fade from view.

This essay explores the possibilities for a productive intellectual exchange between Law and Society scholarship and the New Institutionalism in organizational analysis. The first section of the essay provides a brief introduction to these two traditions. Although hardly a comprehensive survey, this overview establishes a set of common reference points for the subsequent discussion.

We then turn to the "lessons" that each tradition might learn from the other. The second section of the essay outlines several important contributions that institutional analysis might offer to Law and Society scholarship. Law and Society research generally depicts organizations as instrumentally motivated and responsive primarily to the material constraints of legal sanctions. We argue, however, that sociolegal scholars might profitably consider institutional theory's alternative image of organizations as culturally constructed and responsive primarily to the normative and cognitive constraints of legal symbols. Further, sociolegal researchers might benefit from institutional writings on the micro-sociology of individual action and on the macro-sociology of societal rule systems. The third section of the essay turns the tables, exploring the contributions that sociolegal scholarship might offer to institutional analysis. Institutional accounts often depict the law as distinctively explicit, authoritative, and coercive. We argue, however, that organizational scholars might profitably consider the Law and Society movement's alternative image of law as highly ambiguous, political, and constitutive.

The closing sections of the essay seek to synthesize these various lessons. The fourth section extends our earlier arguments to suggest that the relationship between law and organizations is a highly reciprocal one: Each realm interpenetrates, transforms, and reconstitutes the other, with neither being fully exogenous nor causally prior. The brief concluding discussion 
goes on to speculate that such reciprocality may apply not only to legal environments but also to other institutional environments as well. If so, expanded communication between the New Institutionalism and the Law and Society tradition demands renewed scholarly attention to the complex ways in which all institutionalized rule systems are reconstructed and mediated by day-to-day organizational life.

\section{TWO THEORETICAL TRADITIONS}

Many-perhaps most-of the great legal innovations of the 20th century have explicitly taken organizations as their targets. From equal employment opportunity to prison reform, from environmental protection to workplace safety, sociolegal researchers have often found themselves, either by choice or by necessity, studying the impact of law on formal organizations. Some analysts have glossed over this fact by embracing the legal fiction of the formal organization as "corporate person"; however, organizations are more complex than this, and recent accounts of organizationally oriented law have often drawn inspiration from concurrent developments in nonlegal organizational theory. ${ }^{6}$ At the same time, mainstream organizations theorists, for their part, have shown a growing interest in the legal environment; ${ }^{7}$ and a few researchers on both sides of the divide have explicitly sought to promote a more active dialogue between the worlds of legal and organizational scholarship. ${ }^{8}$ With the legal system increasingly operating through and on formal organizations, a strict academic division of labor becomes ever more difficult and counterproductive to maintain.

Still, interdisciplinary communication moves in fits and starts, and even the most relevant developments in a particular field may take some time to percolate across intellectual boundaries. In the hope of accelerating

6. E.g., Edelman, 95 Am. J. Soc.; Rikki Abzug \& Stephen J. Mezias, "The Fragmented State and Due Process Protections in Organizations: The Case of Comparable Worth, " 4 Organization Sci. 433 (1993); Frank R. Dobbin, John R. Sutton, John W. Meyer, \& W. Richard Scott, "Equal Employment Opportunity Law and the Construction of Internal Labor Markets," 99 Am. J. Soc. 396 (1993); Carol A. Heimer, "Explaining Variation in the Impact of Law: Organizations, Institutions, and Profession," in Susan Silbey \& Austin Sarat, eds., Studies in Law, Politics, and Society (forthcoming) ("Heimer, 'Explaining Variation"').

7. E.g., James S. Coleman, Power and the Structure of Society (New York: Norton, 1974); Pamela S. Tolbert \& Lynne G. Zucker, "Institutional Sources of Change in the Formal Structure of Organizations: The Diffusion of Civil Service Reform, 1880-1935," 28 Admin. Sci. Q. 22 (1983); Fligstein, Transformation; Gerald F. Davis, "Agents without Principles? The Spread of the Poison Pill through the Intercorporate Network," 36 Admin. Sci. Q. 583 (1991); Gerald Davis \& Tracy Thompson, "A Social Movement Perspective on Corporate Control," 39 Admin. Sci. Q. 141 (1994).

8. E.g., Philip Selznick, Law, Society, and Industrial Justice (New York: Russell Sage Foundation, 1969) ("Selznick, Law, Society"); Oliver E. Williamson, Markets and Hierarchies (New York: Free Press, 1975); id., 22 J.L. \& Econ. 233 (1979); Edelman, 95 Am. J. Soc. and 97 Am. J. Soc.; Suchman, "On Advice of Counsel"; Robin Stryker, "Rules, Resources, and Legitimacy Processes: Some Implications for Social Conflict, Order, and Change," 99 Am. J. Soc. 847 (1994); Heimer, "Explaining Variation." 
this percolation, we begin by briefly (and selectively) summarizing recent developments in legal and organizational sociology, respectively.

\section{The Law and Society Tradition}

The Law and Society tradition is, itself, an institutionalist perspective, in the broadest sense of the term: In contrast to the "legal formalism" of conventional jurisprudence, ${ }^{9}$ Law and Society scholarship depicts the law as a culturally and structurally embedded social institution. By focusing on law-in-action rather than law-on-the-books, Law and Society research highlights the ways in which extralegal social processes continuously construct and reconstitute the meaning and impact of legal norms. As a social institution, the law encompasses much more than doctrine alone, and sociolegal thought has long emphasized the ways in which formal legal principles may be altered, manipulated, elaborated, or ignored by the social actors who give them life.

Although the bulk of Law and Society research addresses individual behavior or the behavior of various entities within the legal system proper (e.g., juries, judges, lawyers), several foundational studies have directly examined nonlegal organizational settings. In his classic work on exchange relations among Wisconsin businesses, for example, Macaulay found that contract law affected organizational interactions largely indirectly-motivating and facilitating informal bargaining but rarely producing formal legal claims. ${ }^{10}$ Similarly, in another study Macaulay found that the primary impact of laws "protecting" auto dealers against unjust franchise terminations was simply to alter the informal balance of power between the parties, giving dealers somewhat greater leverage against manufacturers in extralegal

9. By "legal formalism" we refer here to the largely asocial treatment of law that has dominated Anglo-American jurisprudence since the late 1800 s (e.g., Christopher C. Langdell, A Selection of Cases on the Law of Contracts (Boston: Little, Brown, 1871); id., Summary of the Law of Contracts (Boston: Little, Brown, 1880)). This philosophy portrays law as an internally coherent and self-contained logical system-a "seamless web" of tightly linked principles, free from class interests and other social influences. Separating law from society, the legal formalist perspective emphasizes abstract doctrines and ahistorical rights, all of which are applied in a uniform, rational, and consistent manner by a neutral and autonomous judiciary. See Thomas Grey, "Langdell's Orthodoxy," 45 U. Pitt. L. Rev. 1 (1983); Anthony Kronman, The Lost Lawyer: Failing Ideals of the Legal Profession (Cambridge, Mass.: Belknap Press, 1993); see also Marc Galanter \& David Trubek, "Scholars in Self-Estrangement: Some Reflections on the Crisis of Law and Development Studies in the United States," 1974 Wis. L. Rev. 1062.

10. Stewart Macaulay, "Non-contractual Relations in Business: A Preliminary Study," $28 \mathrm{Am}$. Soc. Rev. 55 (1963). The businesses that Macaulay studied took pains to avoid or circumvent the formal restrictions of contracts and contract doctrine, generally preferring a "handshake agreement" backed by tacit community norms. Further, where formal contracts did exist and were breached, the contracting parties often eschewed lawsuits in favor of relationship-preserving extralegal adjustments to their original accords. While contract law was not entirely irrelevant, it served primarily to shape transactions at the margins, providing a formal backdrop and a communication device for informal legal arrangements. 
negotiations. ${ }^{11}$ In these and other commercial settings, Law and Society research has repeatedly found that the formal dictates of the law often give way to the informal practices of local business communities.

Rather than simply revealing the gap between law-on-the-books and law-in-action, however, Law and Society research on organizations has emphasized the complex reciprocality between formal and informal legal regimes. In Law, Society, and Industrial Justice, for example, Selznick argued that while internal organizational practices may draw on a fund of public legal experience, day-to-day workplace conflicts also generate an endogenous normative order that ultimately influences formal labor relations law. ${ }^{12}$ Offering a somewhat different approach to the theme of reciprocality, the Critical Legal Studies (CLS) movement has gone so far as to question the very separation of formal law and informal social process. ${ }^{13}$ In this view, law, in response to elite interests, actively constructs many of the concepts and categories that we experience as making up social structure. Legal distinctions such as public versus private, owner versus nonowner, or employer versus employee are not only descriptive of informal social relations, but they are actually constitutive of those relations, as well.14

In short, the Law and Society movement argues for careful attention to the ways in which social structure mediates the impact and meaning of law. This emphasis brings with it a heightened sensitivity to informal norms and to local legal cultures. It also brings an awareness of the complex reciprocality between daily practices and public pronouncements. Increasingly, under the influence of Critical Legal Studies, Law and Society scholarship acknowledges that such reciprocality blurs the distinction between the legal and the social. Formal doctrine helps to constitute informal norms, and, simultaneously, informal norms help to transform formal doctrine. Thus, re-

11. Stewart Macaulay, Law and the Balance of Power: The Automobile Manufacturers and Their Dealers (New York: Russell Sage Foundation, 1966). Both dealers and manufacturers regularly avoided resorting to the official administrative mechanism for deciding franchise disputes, instead developing a complex alternative process for resolving their grievances informally.

12. Selznick, Law, Society. Edelman, 97 Am. J. Soc. (cited in note 2), has recently elaborated this analysis, showing that organizations respond to the vague prescriptions of civil rights law by developing informal models of compliance, which courts then incorporate into formal rulings on what is required to satisfy the statutory mandate. We discuss this argument in greater detail below.

13. See, e.g., Duncan Kennedy, "The Structure of Blackstone's Commentaries," 28 Buffalo L. Rev. 209 (1979); Gabel, 3 Res. L. $\mathcal{F}$ Soc. (cited in note 5); James Boyle, "The Politics of Reason: Critical Legal Theory and Local Social Thought," 133 U. Pa. L. Rev. 685 (1985); Gary Peller, "The Metaphysics of American Law," 73 Cal. L. Rev. 1151 (1985).

14. CLS can, itself, be accused of embracing an overly formalise view of law. The claim that law constitutes social thought patterns (and thus social relations) arguably takes law too seriously and ignores the reciprocal social construction of legal doctrine. Our own view is that CLS is useful because it points out the extent to which law, within any given social context, helps to constitute and reify social relations. However, this constitutive role of law must be understood in the context of the historically contingent institutional regimes that create legal meaning. 
cent sociolegal writings have moved toward depicting law as merely one of many interacting social rule systems. This growing interest in the action of rules systems in general creates a natural affinity between the Law and Society tradition and institutional approaches to the study of organizations.

\section{Institutional Theories of Organizations}

Until the late 1970s, organizational sociology focused primarily on the rational and material aspects of organizational life and downplayed the significance of cultural factors, such as values, beliefs, symbols, rituals, and the like. ${ }^{15}$ In recent years, however, this materialist orthodoxy has increasingly come under challenge from an emerging line of "institutional" scholarship-a perspective that the Powell and DiMaggio anthology both exemplifies and extends. Within organizational sociology, institutional theories are essentially accounts of the causal power of culture and cognition, highlighting precisely those rule-bound and ceremonial aspects of organizational life that previous treatments ignored. Broadly, these new accounts fall into three groups, which might be termed the "normative," the "cognitive," and the "behavioral."16

\section{Normative Institutionalism}

The term "institutionalization" first entered the lexicon of organizational theory through the writings of Philip Selznick and his followers, in the 1940s and 1950s. ${ }^{17}$ DiMaggio and Powell (ch. 1) refer to this work as

15. For surveys of organizational sociology, see W. Richard Scott, Organizations: Natural, Rational, and Open Systems (3d ed. Englewood Cliffs, N.J.: Prentice-Hall, 1992); Gareth Morgan, Images of Organization (Newbury Park, Cal.: Sage Publications, 1986). Early oganizational sociology was dominated by what Morgan refers to as "mechanistic" and "organic" models of organizational life. Researchers differed over whether organizations were best seen as rationally designed social tools (the mechanistic view) or as self-perpetuating natural entities (the organic view); however, most analysts agreed that organizational behavior reflected the concerted efforts of complex hierarchies to pursue objective, material goals-usually through controlled interactions among intraorganizational structural components, and (in some versions) through controlled exchanges with extraorganizational resource environments. Even the handful of conflict-theoretic "political" critiques emerging at the time generally accepted the basic premise that organizations could be understood as goal-driven resource-processing systems-albeit systems divided by factional struggles over who would set the goals and who would control the resources.

16. The approach that we refer to here as "cognitive institutionalism" has often been identified with an emphasis on "institutionalization as a process," while the approach that we designate "behavioral institutionalism" has often been associated with a focus on "institutionalization as a product"; see, e.g., W. Richard Scott, "The Adolescence of Institutional Theory," 32 Admin. Sci. Q. 493 (1987). This alternative terminology reflects the fact that the former camp associates institutionalized rule systems primarily with distinctive cognitive processes, while the latter associates them primarily with distinctive behavioral consequences.

17. Philip Selznick, "Foundations of the Theory of Organizations," $13 \mathrm{Am}$. Soc. Rev. 25-35 (1948); id., TVA and the Grass Roots (Berkeley: University of California Press, 1949) 
the "Old Institutionalism," and they note that it reflected a distinctly "normative" image of social structure and social action. ${ }^{18}$ This early institutional literature drew on structural functionalism and psychoanalytic theory to emphasize the controlling force of moral socialization and internalized value commitments in organizational life. In particular, this work highlighted the ways in which, over time, pragmatic responses to transient organizational crises could gradually become "institutionalized," or "infused with value beyond the technical requirements of the task at hand." 19 In addition, the Old Institutionalism stressed the political role of internal and external constituencies in organizational decision making, arguing that institutionalized value commitments could serve as important symbolic resources in intraorganizational disputes. Thus, for example, Selznick's landmark study of the Tennessee Valley Authority ${ }^{20}$ recounted how early efforts to co-opt local opposition gradually transformed the agency, until its original purposes were eventually lost behind a web of value-laden obligations to various internal and external claimants.

\section{Cognitive Institutionalism}

In contrast to Selznick's emphasis on norms and values, much of the work that Powell and DiMaggio refer to as the "New Institutionalism" adopts a more "cognitive" stance. Tracing its roots to the social phenomenology of Berger and Luckmann, ${ }^{21}$ this perspective stresses the ways in which cultural scripts and typologies construct-or "constitute"-human behavior at a preconscious, taken-for-granted level. Whereas normative models emphasize cultural values about "what ought to be," cognitive models give more weight to cultural assumptions about "what is" and "what can become." Thus, cognitive institutionalists emphasize schemata, expectations, and accounts, rather than mores, commitments, and evaluations. Within the Powell and DiMaggio volume, the foundational essays by Meyer and Rowan (reprinted in ch. 2) and Zucker (reprinted in ch. 4) clearly exemplify this cognitive approach, as does much other work by Meyer, Zucker and their collaborators. ${ }^{22}$

("Selznick, TVA"); id., Leadership in Administration (Evanston, Ill.: Row, Peterson, 1957). For an overview of other works in this tradition, see Charles Perrow, Complex Organizations: $A$ Critical Essay 157-77 (New York: Random House, 1986).

18. Paul J. DiMaggio \& Walter W. Powell, "Introduction," New Institutionalism.

19. Selznick, 13 Am. Soc. Rev.

20. Selznick, TVA.

21. Peter L. Berger \& Thomas Luckmann, The Social Construction of Reality (New York: Doubleday, 1967).

22. John W. Meyer \& Brian Rowan, "Institutionalized Organizations: Formal Structure as Myth and Ceremony" (1977), and Lynne G. Zucker, "The Role of Institutionalization in Cultural Persistence" (1977), New Institutionalism. See also John W. Meyer, "The Effects of Education as an Institution," $83 \mathrm{Am}$. J. Soc. 55 (1977); id., "Institutionalization and the Rationality of Formal Organizational Structure," in John W. Meyer \& W. Richard Scott, eds., 
Cognitive institutionalism is not only psychologically "cooler" than Selznick's earlier rendition, it is less intention-driven as well. Theorists in this camp are much quicker than other institutionalists to question the instrumental, goal-seeking nature of organizational behavior. Rather than reflecting strategic choice, action here reflects unquestioned cognitive definitions of "the way things are" and "the way things are to be done."23 Organizational structure, in turn, echoes deep cultural assumptions ("myths") about competence, volition, identity and causation. ${ }^{24}$ Meyer and Rowan (ch. 2) argue, for example: "In modern societies, the myths generating formal organizational structure ... are highly institutionalized and thus in some measure beyond the discretion of any individual participant or organization. They must, therefore, be taken for granted as legitimate, apart from evaluations of their impact on work outcomes."25

Thus, this cognitive branch of institutionalism stresses the definitional processes by which society delineates organizational types and the labeling processes by which society places actual organizations into specific categories. This orientation appears, for example, in Tolbert and Zucker's study of the spread of municipal civil service reform in turn-of-the-century America. ${ }^{26}$ Questioning traditional technical and political accounts, these authors argue that once the new policies gained a foothold in certain key municipalities, economic and demographic variables ceased to be significant predictors of subsequent diffusion. Rather, the rapid spread of reform government was driven almost entirely by a taken-for-granted perception that this approach was the only obvious and natural way to run a modern metropolis.

\section{Behavioral Institutionalism}

The second strand of New Institutionalism reflected in the Powell and DiMaggio anthology could be termed "behavioral institutionalism." Like cognitive institutionalism, this tradition holds that organizations occupy a socially constructed world of rules and definitions. Behavioral institutionalists, however, focus primarily on the effects of such rules on organizational behavior while remaining agnostic about the mechanisms through which

Organizational Environments: Ritual and Rationality (Beverly Hills, Cal.: Sage Publications, 1983) ("Meyer \& Scott, Organizational Environments"); Lynne G. Zucker, "Organizations as Instixutions," in S. B. Bacharach, ed., Research in the Sociology of Organizations (Greenwich, CT: JAI Press, 1983); Tolbert \& Zucker, 28 Admin. Sci. Q. (cited in note 7); Lynne G. Zucker, ed., Institutional Patterns and Organizations (Cambridge, Mass.: Ballinger, 1988).

23. Scott, 32 Admin. Sci. Q. at 496.

24. Meyer, "Institutionalization and the Rationality of Formal Organizational Structure," in Meyer \& Scott, Organizational Environments.

25. Meyer \& Rowan, "Institutionalized Organizations," New Institutionalism 44.

26. Tolbert \& Zucker, 28 Admin. Sci. Q. 
those effects arise. ${ }^{27}$ Consequently, work in this mold is less committed to a purely cognitive model of human action and is more willing to incorporate rational, normative, and structural factors, as well. Thus, behavioral institutionalists deemphasize internal acceptance of "taken-for-granted assumptions" and focus, instead, on external (often superficial) compliance with specific authoritative mandates-whatever the psychological dynamics underlying such compliance. ${ }^{28}$

This shift allows behavioral institutionalists to acknowledge that, for individual organizations, conformity is often quite rational: When society allocates resources on the basis of categorical rules, compliance makes a great deal of sense-even if the rules and categories, themselves, are entirely socially constructed and arbitrary. For example, in his essay on "Expanding the Scope of Institutional Analysis" (ch. 8), Powell notes:

[If] organizations can manipulate the symbols they present to the external environment, then they must also be adept at producing and controlling symbolic elements. ... And if organizations are rewarded for compliance with external demands, how can we argue that conformity is not based on the calculating behavior of those who are seeking legitimacy?29

By acknowledging such "local rationality," and by linking organizational behavior to the search for legitimacy in the face of rulelike constraints, behavioral institutionalists offer more eclectic accounts than do their cognitive colleagues. The classic example of this approach is DiMaggio and Powell's 1983 essay (ch. 3). ${ }^{30}$ There, the authors posit that institutional isomorphism (the spread of similar structures and practices among organizations subject to the same rule environment) can result not only from normative and cognitive pressures but from coercive authority as well. DiMaggio's essay on art museums (ch. 11) and Galaskiewicz's essay on corporate philanthropy (ch. 12) also exemplify behavioral institutionalism, as do Fligstein's work on the multidivisional corporate form (ch. 13) and Brint and Karabel's study of community colleges (ch. 14)..$^{31}$ In all these ac-

27. W. Richard Scott, "The Organization of Environments: Network, Cultural, and Historical Elements," in Meyer \& Scott, Organizational Environments.

28. Scott, 32 Admin. Sci. Q. at 496 (cited in note 16).

29. Walter W. Powell, "Expanding the Scope of Institutional Analysis," New Institutionalism at $189-90$.

30. Paul J. DiMaggio \& Walter W. Powell, "The Iron Cage Revisited: Institutional Isomorphism and Collective Rationality in Organizational Fields" (1983), New Institutionalism.

31. See, respectively, Paul J. DiMaggio, "Constructing an Organizational Field as a Professional Project: U.S. Art Museums, 1920-1940"; Joseph Galaskiewicz, "Making Corporate Actors Accountable: Institution-Building in Minneapolis-St. Paul"; Steven Brint \& Jerome Karabel, "Institutional Origins and Transformations: The Case of American Community Colleges"; Neil Fligstein, "The Structural Transformation of American Industry: An Institutional Account of the Causes of Diversification in the Largest Firms, 1919-1979," New Institutional ism. See also Steven Brint \& Jerome Karabel, The Diverted Dream: Community Colleges and the 
counts, societal rule systems (including law) shape organizational life not only though the cultural impact of values and definitions but also through the pragmatic linkage between organizational legitimacy and various material incentives and penalties. ${ }^{32}$

As this overview suggests, the New Institutionalism in organizational analysis resonates strongly with the central concerns of Law and Society scholarship. In contrast to previously dominant rational, organic, and political models of organizations, institutionalism takes rules quite seriously. Here, the primary organizational challenge is no longer technical efficiency, competitive fitness, or even raw political power. Rather, organizational life revolves around precisely the sorts of legitimized authority structures and institutionalized rule systems that the Law and Society movement has been studying all along. More than almost any previous organizational perspective (with the possible exception of transaction-cost economics), institutional theory recognizes the importance of rights and obligations and provides a detailed theoretical account of how such lawlike principles enter into day-to-day organizational operations. Institutionalists in the "normative" mold depart from prior scholarship by acknowledging that informal moral appeals often play important roles in shaping organizational action, occasionally overriding the technical requirements of the task at hand. Institutionalists in the "cognitive" mold depart from prior scholarship by acknowledging that rules often operate constitutively to define the meanings of acts and the capacities of actors, rather than simply modifying the costs and benefits of specific practices. Institutionalists in the "behavioral" mold conjoin these insights with more traditional notions of choice and deterrence by acknowledging the subtle interplay between material interests, normative values and cognitive assumptions.

\section{LESSONS FOR LAW AND SOCIETY FROM INSTITUTIONAL THEORY}

Given these affinities between organizational institutionalism and sociolegal scholarship, if sociologists of law wish to develop a better understanding of how rules affect organizations, institutional theory provides a sensible place to turn. To date, Law and Society research has relied almost exclusively on older, classical models of organizational life. However, rational materially driven organizational behavior seems out of place in an account of law that highlights the normative culturally driven aspects of

Promise of Educational Opportunity in America, 1900-1985 (New York: Oxford University Press, 1989) ("Brint \& Karabel, Diverted Dream"); Neil Fligstein, "The Spread of the Multidivisional Form among Large Firms, 1919-1979," 50 Am. Soc. Rev. 377 (1985).

32. Mark C. Suchman, "Managing Legitimacy: Strategic and Institutional Approaches," 20 Acad. Management Rev. 571-610 (1995). 
individual behavior. By offering a more cultural, constructionist image of organizations, institutional theory holds the potential for truly integrating organizational analysis into the mainstream of Law and Society research.

The appeal of institutionalism to Law and Society researchers does not end with its portrayal of formal organizations, however. As Powell and DiMaggio's wide-ranging anthology illustrates, institutional theories of organizations are only a subset of institutional theory as a whole: The broader institutional literature contains extended discussions of more "micro" individual behaviors and more "macro" societal regimes, as well. While Law and Society work, too, has devoted considerable attention to these micro- and macro-sociological topics, institutional theory grows from different intellectual roots and different empirical soil. Consequently, a thoughtful crosspollination between the two traditions might bear fruit at three distinct levels of analysis: (1) the level of individual action, (2) the level of organizational behavior, and (3) the level of societal rule systems.

\section{Individual Action}

In the micro-level description of human action, both institutional theory and the sociology of law have focused heavily on the tension between rational self-interest and cultural embeddedness. Institutional theory, however, has gone much further than has Law and Society work in differentiating the normative and cognitive aspects of culture and in developing coherent empirical accounts of how human decisions are affected by each. Consequently, the Powell and DiMaggio anthology can offer Law and Society scholars useful guidance in distinguishing the various models of action from one another, exploring their origins and implications, and examining their interplay across a wide range of empirical settings.

Sociolegal studies have generally addressed fundamental questions of human action as part of a more concrete discussion of why people obey the law. ${ }^{33}$ Although this literature is both extensive and diverse, it has often taken the form of a relatively bipolar debate between "rational" models, on the one hand, and "normative" or "moral" models, on the other. The rational choice camp (including many sociologists and nearly all economists) begins with the assumption that people usually act in ways that maximize their own material well-being. From this assumption, rational choice theorists derive an elaborate apparatus of "deterrence theory"-modified occasionally by empirical findings on certainty versus severity of punishment, risk aversion, information costs, decision bias, and the like. ${ }^{34}$ The normative

33. See, e.g., Tom R. Tyler, Why People Obey the Law (New Haven, Conn.: Yale University Press, 1990) ("Tyler, Why People Obey").

34. See, e.g., George Antunes \& A. L. Hunt, "The Impact of Certainty and Severity of Punishment on Levels of Crime in American States: An Extended Analysis," 64 J. Criminal L. 
camp, in contrast, holds that self-interest plays only a limited role in human decision making, particularly with regard to legal compliance. Instead, normative theorists assert, people act according to internalized cultural standards of right and wrong, seeking to "do the right thing" even at some personal cost. ${ }^{35}$ Thus, in the normative view, responses to law have more to do with socialization, morality, and legitimacy than with self-interest, utility, and deterrence. ${ }^{36}$

Significantly, although the rational/normative distinction forms a comfortable dichotomy, institutional theorists emphasize that these two approaches do not, in fact, occupy the entire field. Despite their obvious differences, rational and normative models share a common presumption that the roots of human behavior can be found in conscious reasoning (whether based on tastes or on morals). Consequently, both models neglect or marginalize the role of less overt, more taken-for-granted understandings about identity, capacity, and causality. As Friedland and Alford (ch. 10) ${ }^{37}$ point out, however, such tacit cognitive assumptions are often prior toand determinative of-both cost-benefit analysis and moral reasoning. Although rarely subjected to conscious scrutiny, cultural frames affect the meanings that behaviors carry, both for oneself and for one's community. Once the question of meaning has been resolved, decisions themselves often become virtually automatic.

Long neglected within sociolegal studies, the analysis of such "constitutive" rules has recently become a centerpiece of the Critical Legal Studies movement, and even traditional scholars are realizing that they ignore this aspect of the law at their own peril. ${ }^{38}$ Unfortunately, the CLS treatment of constitutive rules tends to be somewhat mystical and nonempirical, with more attention being devoted to interpreting the hidden tropes of legal texts than to fleshing out a model of human action that could stand on a

E् Criminology 486 (1973); Jack P. Gibbs, "The Deterrence Doctrine: Theory, Research, and Penal Policy," in Leon Lipson \& Stanton Wheeler, eds., Law and the Social Sciences (New York: Russell Sage Foundation, 1986).

35. Tyler, Why People Obey.

36. Richard D. Schwartz \& Sonya Otleans, "On Legal Sanctions," 34 U. Chi. L. Rev. 274 (1967); Leonard Berkowitz \& Nigel Walker, "Laws and Moral Judgements," 30 Sociometry 410 (1967). Cf. Harold G. Grasmick \& Robert J. Bursik, Jr., "Conscience, Significant Others, and Rational Choice: Extending the Deterrence Model," 24 Law \& Soc'y Rev. 837 (1990).

37. Roger Friedland \& Robert R. Alford, "Bringing Society Back In: Symbols, Practices and Institutional Contraditions," New Institutionalism.

38. The burgeoning literature on "procedural justice" (e.g., Tom R. Tyler \& E. Allan Lind, The Social Psychology of Procedural Justice (New York: Plenum Press, 1988) ("Tyler \& Lind, Social Psychology"), offers a telling example of how sociolegal studies might benefit from greater sensitivity to the constitutive aspects of the law. Although this research program has developed a substantial body of evidence regarding which sorts of legal procedures Americans consider most fair, it has given little attention to the possibility that these popular standards might, themselves, be socially constructed-and constituted, in part, by notions of due process embedded and embodied in the American legal system. Cf. Edelman, $95 \mathrm{Am}$. J. Soc. (cired in note 2); Ronald L. Jepperson \& John W. Meyer, "The Public Order and the Construction of Formal Organizations," New Institutionalism. 
par with the rational and normative alternatives. As a result, the CLS literature abounds with assertions that "law constitutes social reality," but it contains remarkably few descriptions of precisely when or how individuals experience or respond to this constitutive pressure.

It is here that institutional theorists may have the most to offer: While institutional theory shares CLS's interest in how rules constitute action, it enjoys a much closer linkage to sociological and social-psychological work on cognition, decision making, labeling, interaction ritual, and accounts. ${ }^{39}$ The organizational literature explicitly recognizes the role of social institutions and professional discourses (such as the law) in constructing societal hegemony; ${ }^{40}$ however, it also links such macro-sociological concerns with an increasingly sophisticated micro-sociological treatment of the role of social identities, cognitive schemata and behavioral scripts in shaping individual action. Rather than simply asserting that rules constitute society, institutional theory has begun to model how such constitution occurs, and equally importantly, it has attempted to do so in a way that is amenable to sustained empirical scrutiny. ${ }^{41}$

Institutional theorists also increasingly address the possibility that rational, normative, and cognitive decision processes can peacefully coexist. The foundational essays by Meyer and Rowan (reprinted in ch. 2) and DiMaggio and Powell (reprinted in ch. 3), for example, describe how selfinterested organizations may find that in certain settings technically irrational structures represent strategically rational reactions to institutional constraints. ${ }^{42}$ In the presence of contradictory environmental demands, responses such as "loose-coupling" and "ceremonial conformity" may enhance organizational effectiveness even as they impair organizational efficiency. Conversely, more recent institutional work such as Friedland and Alford's essay (ch. 10) highlights the ways in which both the technologies and the preferences underlying rational action may, themselves, be socially constructed, taken-for-granted and, to some extent, mythical.43 Perhaps most

39. Paul J. DiMaggio \& Walter W. Powell, "Introduction," New Institutionalism 16 ff.; see also James G. March, "Decisions in Organizations and Theories of Choice," in A. H. Van de Van \& W. F. Joyce, eds., Perspectives on Organization Design and Behavior (New York: Wiley, 1981) ("Van de Van \& Joyce, Perspectives").

40. E.g., DiMaggio, "Constructing an Organizational Field," New Institutionalism. 22).

41. See, e.g., Zucker, "Role of Institutionalization," New Institutionalism (cited in note

42. Meyer \& Rowan, "Institutionalized Organizations," New Institutionalism (cited in note 22); DiMaggio \& Powell, "Iron Cage Revisited," New Institutionalism (cited in note 30).

43. Friedland \& Alford, "Bringing Society Back In," New Institutionalism; see also Frank R. Dobbin, "The Origins of Economic Principles: Entrepreneurs and Public Policy in 19th Century America," in W. Richard Scott \& Søren Christensen, The Institutional Construction of Organizations (Newbury Park, Cal.: Sage Publications, 1995) ("Scott \& Christensen, Institutional Construction"); Suchman, "On Advice of Counsel" (cited in note 3); Lauren B. Edelman, Christopher Uggen, \& Howard S. Erlanger, "The Endogeneity of Legal Regulation: Grievance Procedures as Rational Myth" (presented at Law \& Society Association annual meeting, Toronto, 1995) ("Edelman et al., 'Endogeneity"'). 
profoundly, Zucker (ch. 4) and other cognitive institutionalists have emphasized that maintaining a meaningful social reality can often become a valued end in itself.44 With "meaningfulness" as their strategic goal, actors may tacitly collude to preserve a social system's underlying cognitive assumptions-even to the extent of repressing (both psychologically and politically) alternatives that might bring those assumptions into question. ${ }^{45}$

Institutional theory, then, provides significant insights into the socially constructed nature of individual action--insights bearing directly on how we understand compliance with the law, both within and outside organizations. An extended dialogue between the new institutionalism and the sociology of law holds great promise for elaborating and concretizing the CLS analysis of constitutive law and for transcending the stark dichotomy between rational and normative mechanisms of compliance. Although the institutional literature may not contain all the answers, it has gone a long way toward framing a useful set of questions.

\section{Organizational Behavior}

The second and most significant area in which the New Institutionalism might enrich the Law and Society tradition centers on the conceptualization of organizations themselves. ${ }^{46}$ Although Law and Society work has been quite sophisticated in its analysis of the social nature of legal institutions, it tends to neglect the social nature of organizations. Returning to a formalism that it rejected in the study of law, Law and Society research often sees organizations as unitary rational actors whose responses to law are instrumental, substantive, and largely confrontational. Law and Society scholars have long recognized that individual-level compliance decisions involve not only rational calculations but also a variety of normative and cognitive processes as well. However, these same scholars continue to view organization-level decisions as flowing almost entirely from narrow considerations of technical efficiency and profit maximization. Further, by reducing organizational compliance to self-interested cost-benefit analysis, the Law

44. Zucker, "Role of Instizutionalization," New Institutionalism (cited in note 22). See also Meyer \& Rowan, "Institutionalized Organizations," New Institutionalism (cited in note 22); Friedland \& Alford, "Bringing Society Back In," New Institutionalism (cited in note 37).

45. Meyer and Rowan refer to this meaning-preserving collusion as embodying a "logic of confidence" - a double-entendre evoking both "public confidence" and the "confidence game." Meyer \& Rowan, "Institutionalized Organizations," New Institutionalism.

46. The relevance of institutionalism to sociolegal work on organizations is evident in the fact that virtually all recent students of law and organizations draw heavily on this tradition. See, e.g., Dobbin et al., "Expansion of Due Process" (cited in note 2); Edelman, 95 Am. J. Soc. (cited in note 2); Creighton, "Emergence" (cited in note 3); Edelman, 97 Am. J. Soc. (cited in note 2); Dobbin et al., 99 Am. J. Soc. (cited in note 6); Suchman, "On Advice of Counsel." 
and Society literature consigns organizations to a marginal role, at best, in the constitution of the larger legal order.

The New Institutionalism, in contrast, reconstructs organizational analysis around the same types of culturalist, constructionist arguments that Law and Society scholars have long applied to most other aspects of social life. ${ }^{47}$ Broadly speaking, the New Institutionalism provides three insights of particular value for students of law and organizations: (1) organizations are complex social actors whose behavior is shaped as much by their cultural environments as by rational calculations and technical imperatives; (2) because compliance is culturally defined, organizations often react to their rule environments through symbolism as well as through substance; and (3) such symbolic displays can operate, at the environmental level, to foster institutional isomorphism and to channel the social construction of legality.

\section{Organizations as Cultural}

Traditional Law and Society thinking allows little room for the possibility that organizations could, like individuals, experience stigma and shame, develop habits, respond to custom and morality, or consider the legitimacy of their actions. This assumption has substantial implications for how sociolegal scholars understand (or misunderstand) the relationship between organizations and law: If organizations lack consciences, pocketbook control must be the primary method of regulating their behavior. ${ }^{48}$ Further, one should expect the rational profit-maximizing organization to respond to loopholes in the law and weaknesses in enforcement by subverting or ignoring any legal requirements that threaten its immediate financial health. ${ }^{49}$

47. Abzug \& Mezias, 4 Organization Sci. (cited in note 6).

48. Christopher Stone, Where the Law Ends: The Social Control of Corporate Behavior (New York: Harper \& Row, 1975) ("Stone, Where the Law Ends").

49. Stone, for example, shows how organizational structure encourages inattention to legal requirements; Vaughan argues that organizational structure encourages individuals within organizations to place organizational goals above legal requirements; and Burk contends that individuals in organizations use legal requirements to advance other, extralegal interests. Stone and Vaughan show how attributes of bureaucracy such as task specialization, decentralized decision making, and interdivisional competition are conducive to noncompliance. In addition, Katz points out that officials within organizations often mask violations from outside review. Stone, Where the Law Ends; Diane Vaughan, Controlling Unlawful Organizational Behavior: Social Structure and Corporate Misconduct (Chicago: University of Chicago Press, 1983); James Burk, Values in the Marketplace: The American Stock Market Under Federal Securities Law (New York: Walter de Gruyer, 1988); Jack Katz, "Cover-Up and Collective Integrity: On the Natural Antagonism of Authority Internal and External to Organizations," 25 Soc. Prob. 3 (1977). See also Frederick Wirt, The Politics of Southern Equality: Law and Social Change in a Mississippi County (Chicago: Aldine, 1970); Colin S. Diver, "The Judge as Political Powerbroker: Superintending Structural Change in Public Institutions," 65 Va. L. Rev. 43 (1979); William H. Clune, "A Political Model of Implementation and the Implications of the Model for Public Policy, Research, and the Changing Role of Lawyers," 69 lowa L. Rev. 47 (1983); Keith Hawkins, Environment and Enforcement (Oxford: Clarendon Press, 1984) ("Hawkins, Environment and Enforcement"); Blumrosen, Modern Law (cited in note 1). 
Moreover, although such self-interested organizations may collude in their noncompliance, they will experience no "social sentiments" or altruistic attachments to a broader collectivity.

Unfortunately, this confrontational imagery meshes poorly with Law and Society research reporting extensive ambiguity and contradiction in the legal environments that most organizations face. ${ }^{50}$ Given the apparent frailty of direct legal controls, either the law is simply irrelevant to organizational life, or it must be affecting organizations in relatively noninstrumental or indirect ways. For those who favor the latter explanation, institutional theory offers a useful model of how organizations might respond to such a diffuse and muddled rule system.

Although the Powell and DiMaggio anthology contains few discussions of law per se, it provides a powerful antidote to the exclusive focus on organizational rationality in most sociolegal work. Arguing against the image of organizations as "rational systems," the collected essays suggest that institutional factors often lead organizations to conform to societal norms even when formal enforcement mechanisms are highly flawed. Frequently cited institutional influences include historical legacies, cultural mores, cognitive scripts, and structural linkages to the professions and to the state. Each, in its own way, displaces single-minded profit maximization with a heightened sensitivity to the organization's embeddedness within a larger social environment. More broadly, the New Institutionalism emphasizes the power of cultural rule systems to shape both organizational environments and managerial behaviors; and in doing so, it holds out the promise of moving sociolegal scholarship to the center stage of organizational analysis-and vice versa.

Along these lines, the essays by Meyer and Rowan (ch. 2), DiMaggio and Powell (ch. 3), and Scott and Meyer (ch. 5) all emphasize the concept of "institutional isomorphism" as a fundamentally nonrational explanation for the homogenization of organizational forms. ${ }^{51}$ This account posits that organizations adopt many practices and structures not for efficiency reasons but because the cultural environment constructs adoption as being the proper, legitimate, or natural thing to do. DiMaggio and Powell (ch. 3) de-

50. The Law and Society literature is replete with cases in which legal "controls" on organizational behavior consist almost entirely of broad and ambiguous mandates, with little "plain meaning." Usually, this is no accident: Statutory ambiguity results largely from corporate lobbying, which tends to dilute strong legislative language. For similar reasons, laws targeted toward organizations tend to address procedure more than substance, to have weak and poorly funded enforcement mechanisms, and to provide little feedback on what constitutes compliance. See, e.g., Paul Burstein, Discrimination, Jobs, and Politics: The Struggle for Equal Employment Opportunity in the United States since the New Deal (Chicago: University of Chicago Press, 1988); Edelman, $97 \mathrm{Am}$. J. Soc. (cited in note 2).

51. Meyer \& Rowan, "Institutionalized Organizations," New Institutionalism; DiMaggio \& Powell, "Iron Cage Revisited," New Institutionalism (cited in note 30); Richard Scott \& John W. Meyer, "The Organization of Societal Sectors: Propositions and Early Evidence" (1983) New Institutionalism. 
velop this idea most explicitly by articulating three distinct types of institutional isomorphism:52 "mimetic isomorphism" arises when organizations copy the apparently successful practices of other, similar organizations; "normative isomorphism" arises when organizations import the practices of professionals and other organized value carriers; and "coercive isomorphism" arises when organizations submit to the demands of powerful external actors, such as the regulatory agencies of the state..$^{53}$ While normative, cognitive, and behavioral institutionalists (see above) differ in the degree to which they link isomorphism to the conscious pursuit of organizational legitimacy, ${ }^{54}$ all agree that institutional environments, rather than raw effciency concerns, drive organizational life.

Extended to the legal realm, this notion challenges the conventional assumption that laws affect organizations only by altering the immediate economic costs of specific sanctioned activities. Depicting legal compliance as institutional isomorphism recasts law as a broad cultural framework that influences organizations both mimetically and normatively, not merely through coercive material incentives. .5

\section{Compliance as Symbolic}

Once one acknowledges that organizations respond as readily to cultural considerations as to material sanctions, other traditional Law and Society assumptions about organizations become problematic, as well. In particular, because organizations are sensitive to law's cultural components, they will often react to legal mandates through culturally meaningful signals and gestures, rather than through simple obedience or resistance. Thus, an institutional perspective on organizational behavior cautions against Law and Society's inclination to see compliance solely in substantive and concrete terms. ${ }^{56}$ By emphasizing ritual performances and mythic accounts, institutionalists suggest that organizational compliance may be largely formal and symbolic-although immensely consequential, nonetheless. ${ }^{57}$

Institutional regimes revolve largely around preserving an appearance of shared meaning, even if the formal structures that convey this appearance

52. DiMaggio \& Powell, "Iron Cage Revisited," New Institutionalism 67-74.

53. In our discussion of how Law and Society work may inform the New Institutionalism (below), we challenge the common institutionalist assumption that legal mandates operate primarily through coercion.

54. Suchman, 20 Acad. Management Rev. (cited in note 32).

55. For examples of this approach, see Dobbin et al., "Expansion of Due Process" (cited in note 2); Edelman, $95 \mathrm{Am}$. J. Soc. (cited in note 2); id., $97 \mathrm{Am}$. J. Soc. (cited in note 2); Abzug \& Mezias, 4 Organization Sci.; Heimer, "Explaining Variation" (cited in note 6).

56. For a rare Law and Society analysis of symbolic response, see Hawkins, Environment and Enforcement.

57. See Friedland \& Alford, "Bringing Society Back In," New Institutionalism (cited in note 37); see also Edelman, $97 \mathrm{Am}$. J. Soc. (cited in note 2). 
are only loosely coupled to substantive practices. Meyer and Rowan (ch. 2) ${ }^{58}$ refer to this mixture of ceremonial display, substantive decoupling and pro forma evaluation as a "logic of confidence," and they argue that it represents a central dynamic of most institutional environments. An extension of this analysis to law would suggest that legal rules often invite primarily symbolic responses, because of the cultural import placed on visible demonstrations of organizational attentiveness. ${ }^{59}$ If such symbolic responses are as pervasive as institutional theory suggests, it is probably a mistake to lump them together with either substantive compliance or substantive resistance, rather than taking them seriously in their own right.

Institutionalists, moreover, would adamantly resist the claim that symbolic displays are merely evasive maneuvers. Although cynical "sham" responses remain a possibility, institutional accounts see symbolic activities as being largely sincere. Through their ritual performances, organizations struggle to preserve fragile meaning-giving myths in the face of inconsistent cultural demands and uncertain technical capacities. It is often easier to proclaim flexibility, efficiency, aggressiveness, accountability and impartiality in ceremony than to be all of these things in practice.

Further, an institutional perspective highlights the ways in which ceremonial responses serve to constitute and reconstitute the larger institutional environment. As Friedland and Alford (ch. 10) point out, when cultural beliefs matter, ritual and symbolism can have long-lasting substantive impacts:

When social analysts have analyzed the "symbolic" or "ritual" role of different kinds of activities, ... they have often studied those instances where the activity doesn't organize material life, where it is a hollow legitimation. . . . But through [ritual behaviors], individuals reproduce the symbolic order of the institution and [its] social relationships. . . . Institutional transformations are therefore associated with the creation of both new social relationships and new symbolic orders. ${ }^{60}$

Cultural environments, then, not only encourage symbolic organizational responses, they also rely on such responses for their continuing reproduction and development.

\section{Regulation as Social Construction}

The argument that symbolic behaviors may have significant institutional consequences leads directly to the third major insight of institutional

58. Meyer \& Rowan, "Institutionalized Organizations," New Institutionalism 58 ff. (cited in note 22).

59. See, e.g., Edelman, $97 \mathrm{Am}$. J. Soc. (cited in note 2).

60. Friedland \& Alford, "Bringing Society Back In," New Institutionalism 250. 
theory: Organizations and rule environments rarely encounter each other autonomously and confrontationally. Rather, both are constituted together, as part of a larger process of institutional "structuration." 61 Thus, the relationship between organizational practice and legal mandate evolves collectively over time, may be collaborative rather than confrontational, and involves normative and cognitive as well as instrumental dynamics.

Despite some discussion of how certain industry cultures may encourage member firms to break or resist the law, ${ }^{62}$ too much sociolegal scholarship treats organizations merely as social isolates in a Hobbesian war of each against all. In this view, individual firms simply pursue their own narrow self-interests, in competition with one another and, when necessary, in contravention of the law. Thus, the Law and Society account relies almost exclusively on models of organization-level choice, in which preexisting organizations weigh the costs and benefits of legal compliance, given some set of exogenous interests in profits, efficiency, and the like. The institutional account, on the other hand, invokes more macrosociological models of environment-level structuration, in which entire sectors of social life become institutionalized concurrently, through the simultaneous formulation of governing principles, articulation of legitimate interests, and generation of appropriate organizations. While the next section of this essay focuses on the structure of such institutional regimes themselves, here we emphasize the extent to which these cultural environments endogenously construct both the definition of legal compliance and the population of compliant organizations.

Given ambiguity and complexity in the law, environment-level dynamics such as mimetic and normative isomorphism play a central role in transforming vague legal strictures into concrete organizational practices. Diffuse, contradictory laws create normative and cognitive uncertainties that impel organizations to search their environments for successful models of compliance. ${ }^{63}$ Looking to one another, to the professions, and to the state, organizations impute meanings to nebulous "mandates" and then structure their operations accordingly. ${ }^{64}$ Thus, the definition of compliance emerges collectively and often cooperatively within an organizational com-

61. DiMaggio \& Powell, "Iron Cage Revisited," New Institutionalism (cited in note 30); cf. Anthony Giddens, Central Problems in Social Theory: Action, Structure, and Contradiction in Social Analysis (Berkeley: University of California Press, 1979).

62. See, e.g., Diane Vaughan. "Transaction Systems and Unlawful Organizational Behavior," 29 Soc. Prob. 373 (1982).

63. Edelman, 97 Am. J. Soc.

64. Ironically, the New Institutionalism suggests that the more uncertain the law is, the more intense such sense-making activity will be. See, e.g., DiMaggio \& Powell, "Iron Cage Revisited," New Institutionalism 77 ("The greater the extent to which technologies are uncertainty or goals are ambiguous withing a field, the greater the rate of isomorphic change"). 
munity, and compliant behavior is motivated more by cultural norms and accounts than by the imminent threat of legal sanctions. ${ }^{65}$

In some contexts, institutional theorists might go even further, to argue not only that rules draw meaning from organizations but also that organizations draw strength from rules. Far from seeing environmental rule systems solely (or even primarily) as impediments to organizational freedom, institutionalists tend to see rules as justifying, authorizing, and even constructing organizational activity. Likening rules to cultural armatures, institutionalists downplay the distinction between constraint and support. Scott and Meyer (ch. 5), for example, hypothesize: "strong and stable organizational forms can arise in either technical or institutional environments, but one of these two sets of constraints/supports must be present." 66 This view deemphasizes the confrontational aspects of organizations' relationships to law, and it suggests that at times organizations may even seek and exalt legal attention, as part of larger projects of structuration and legitimation. ${ }^{67}$

The three major institutional themes discussed above-the cultural character of organizations, the symbolic nature of compliance, and the social construction of environments-are all reflected in Edelman's recent work on civil rights law: ${ }^{68}$ The Equal Employment Opportunity mandates of the 1960 s, together with the social movements that produced them, enunciated new rights to fair treatment in the workplace and provided the public with new expectations, norms, and bases for criticizing managerial behavior. Although direct law enforcement efforts were spotty at best, considerations

65. There is considerable empirical support for the New Institutionalist version of organizational compliance with law. Analyses of the diffusion of various responses to law often show that the rate of adoption is proportionate to the prevalence of such structures in the population, which supports the notion of normative isomorphism. Edelman, $95 \mathrm{Am}$. J. Soc. (cited in note 2); id., 97 Am. J. Soc. (cited in note 2); John R. Sutton, Frank R. Dobbin, John W. Meyer, \& W. Richard Scott "Legalization of the Workplace," 99 Am. J. Soc. 944 (1994). Further, Edelman, Uggen, and Erlanger find that while employers adopt discrimination grievance procedures in the belief that such procedures will reduce the likelihood of litigation, there is little objective evidence to validate this belief. The personnel and legal professions, however, have actively promulgated this unsubstantiated assumption. Edelman et al., "Endogeneity" (cited in note 43).

66. Emphasis added; Scott \& Meyer, "The Organization of Societal Sectors," New Institutionalism 124 (cited in note 51).

67. While it might initially seem contradictory to claim both that organizations construct the meaning of law and that law constructs the capacities of organizations, an institutional perspective would suggest that this paradox rests on a faulty premise. The contradiction arises only if one assumes that each organization encounters the law in isolation from all others and that either the law or the organization or both must be exogenous to this encounter. In the institutional model, however, legal and organizational forms emerge together, as part of a larger process of sector-level development. Both laws and organizations gain solidity from the structuration of an entire institutional environment, and while both play important parts in this structuration, neither is purely an instrument of the other.

68. Edelman, $95 \mathrm{Am}$. J. Soc. (cited in note 2); id., $97 \mathrm{Am}$. J. Soc. (cited in note 2); Lauren B. Edelman \& Stephen Petterson, "Symbols and Substance in Organizational Response to Civil Rights Law" (Dep't of Sociology, University of Wisconsin, Madison, 1994) ("Edelman \& Petterson, 'Symbols and Substance"); Edelman et al., "Endogeneity." 
of legitimacy and propriety led many employers to establish due process protections voluntarily, in a symbolic display of fidelity to the cultural ideals underlying the new laws. Further, those organizations that were closest to their institutional environments-whether because of dependence on government contracts or because of greater public visibility-responded earlier and at higher rates than others. This pattern strongly suggests that cultural rather than technical factors drove their reactions.

Normative and mimetic isomorphism were apparent in this process, as well. Personnel and legal professionals, in particular, took an active role in devising and promoting formal symbols of attentiveness, such as affirmative action offices and internal grievance procedures. Courts, for their part, reified these symbolic responses by using them as ready-made yardsticks for compliance. On the whole, the judiciary simply deferred to the standards of behavior that were becoming institutionalized within the relevant organizational populations, validating these indigenous practices as indicators of fair treatment. ${ }^{69}$ Nonetheless, all of this symbolic activity was hardly inconsequential: Edelman and Petterson report that although affirmative action plans and EEO offices exert little direct impact on the workforce representation of minorities and women, these gestures appear to engender stronger organizational commitments to affirmative action goals. ${ }^{70}$ To recast this history in terms of either evasion or submission would be misleading; more accurately, organizations actively participated in defining the cultural meaning of the initially ambiguous statutes to which they were subject.

As this example illustrates, the New Institutionalism has much to offer to Law and Society research on organizations. Institutional theory replaces the notion of organizations dodging law in pursuit of profits with a vision of organizations responding-much like individuals-to rituals, norms, shame, and legitimacy, even when the threat of legal sanctions is rather remote. It further argues that these responses are frequently symbolic rather than substantive and that they are often embedded in an ongoing process of environmental structuration. Significant in their own right, these insights point toward a larger lesson, as well: By depicting organizations as social entities that are both responsive to, and constitutive of, their rule environments, the New Institutionalism reasserts the crucial theoretical importance of the often-neglected territory at the intersection of legal and organizational analysis.

\section{Societal Rule Systems}

A final area in which institutional insights might prove valuable to sociolegal scholars involves the social construction of societal rule sys-

69. Edelman, 97 Am. J. Soc.; Edelman et al., "Endogeneity."

70. Edelman \& Petterson, "Symbols and Substance." 
tems-or, in the language of institutional theory, "regulatory regimes" and "polity types." Here, the New Institutionalism highlights the cultural and historical forces promoting coherence within institutional orders. In so doing, it offers a provocative challenge to the deeply ingrained "rule skepticism" of the Law and Society tradition. ${ }^{11}$

Historically, the Law and Society Movement has forcefully debunked the legal system's pretensions of deterministic coherence, contending instead that legal interpretation is more an act of autonomous political creativity than an exercise in fixed deductive logic. Taking this argument to its logical extreme, CLS theorists have gone so far as to advocate an account built on radical indeterminacy, in which legal interpretation is merely a post hoc justification for decisions adopted on other grounds. This image of rules-as-epiphenomena fits reasonably well with a crass instrumentalist depiction of the legal system, in which legal events follow transparently from exogenous political pressures, with little serious doctrinal intervention. But more recent currents in Law and Society thought mix uneasily with the postulate of complete legal indeterminacy. One can hardly argue, for example, that law operates as a semi-autonomous source of hegemonic ideology ${ }^{72}$ without implying that the internal structure of legal rules may, in fact, matter. ${ }^{73}$ To date, however, sociolegal studies have glossed over this tension between indeterminacy and hegemony, leaving in place the basic assumption that law is infinitely malleable and that its consistencies, like its contradictions, are merely artifacts of political expedience and historical coincidence..$^{74}$

The New Institutionalism, in contrast, takes the internal structure of rule systems quite seriously. Although, as we will argue below, Institutional Theory is not particularly sophisticated in its treatment of the law per se, the DiMaggio and Powell volume offers important insights into the cultural forces shaping social rules more generally. In particular, institutional theo-

71. "Rule skepticism" actually predates the Law and Society tradition, having first been introduced by the Legal Realists in the 1930s. See, e.g., Karl Llewellyn, "A Realistic Jurisprudence-The Next Step," 30 Colum. L. Rev. 431 (1930)."

72. See, e.g., Alan Hunt, "The Ideology of Law: Advances and Problems in Recent Applications of the Concept of Ideology to the Analysis of Law," 19 Law \& Soc'y Rev' 11 (1985).

73. Other versions of structuralism are reasonably compatible with radical indeterminacy: One could, for example, formulate a model in which the relative autonomy of the law would rest solely on a system of material checks and balances, with doctrine playing little independent role. However, such materialist structuralism, like crass instrumentalism, enjoys little support in contemporary sociolegal circles. Rather the tone of the debate is closer to the position of Critical Legal Studies, which holds that contradictions among legal principles are so consequential that by revealing them, one can actually problematize and delegitimize the social order as a whole.

74. Under the rubric of "legal culture," sociolegal scholars have begun to reexamine the internal consistency of formal and informal rule systems, in much the manner advocated here. To date, however, these investigations have been strong on description and weak on theory. Greater dialogue between students of legal culture and their counterparts in institutional analysis might go a long way toward remedying this imbalance. 
rists have recently begun to assemble an extended discussion of various "regulatory regimes" and of the cultural constraints producing internal coherence among those regimes' component parts. Without claiming that rules possess an exogenous "plain" meaning, institutionalists nonetheless draw on structuration theory 75 and social phenomenology 76 to argue that coherent and stable local understandings can emerge through an ongoing historical process of interaction, typification, and institutionalization. In this view, meanings become "plain" to the extent that a particular cultural discourse makes certain interpretations appear more plausible, natural, and compelling than others. The progress of this meaning-building process, for its part, depends heavily on how various competing readings mesh with other already-institutionalized elements of the larger regime. The result is a tendency for rule systems to preserve internal consistency, even as they generate a constant stream of new elaborations, extensions and distinctions.

This argument about the social construction of coherent meanings appears most clearly in DiMaggio and Powell's discussion of "organizational fields" (ch. 3) 77 and in Jepperson and Meyer's discussion of "national polities" (ch. 9). ${ }^{78}$ Each essay, in its own way, bears direct relevance to the sociology of law. In chapter 3, DiMaggio and Powell define an "organizational field" as "those organizations that, in the aggregate, constitute a recognized area of institutional life: key suppliers, resource and product consumers, regulatory agencies, and other organizations that produce similar services and products." ${ }^{.79}$ This intermediate level of analysis, the authors claim, is the primary locus of institutional structuration: Although the practices of organizational fields are initially indeterminate, "professional projects" and "institutional entrepreneurship" can engender a cascade of isomorphism, in which "actors making rational decisions construct around themselves an environment that constrains [them] in later years." $80 \mathrm{Re}$ searchers have yet to apply this field concept in a rigorous way to the legal system; however, the analogy would carry some interesting implications for discussions of legal indeterminacy. Just as professionalization and institution building may constrain initially indeterminate industrial processes, so, too, may the elaboration of the legal profession and the development of a self-

75. Anthony Giddens, The Constitution of Society (Berkeley: University of California Press, 1984).

76. Peter L. Berger \& Thomas Luckmann, The Social Construction of Reality (New York: Doubleday, 1967).

77. DiMaggio \& Powell, "Iron Cage Revisited," New Institutionalism (cited in note 30).

78. Jepperson \& Meyer, "Public Order," New Institutionalism (cited in note 38).

79. DiMaggio \& Powell, "Iron Cage Revisited," New Institutionalism 64-65. Cf. Scott \& Meyer, "The Organization of Societal Sectors," New Institutionalism $117 \mathrm{ff}$. (cited in note 51). DiMaggio and Powell's concept of the "organizational field" is effectively identical to Scott \& Meyer's concept of the "societal sector," and most institutional theorists treat the two terms as virtually synonymous. 30).

80. DiMaggio \& Powell, "Iron Cage Revisited," New Institutionalism 65 (cited in note 
conscious judiciary constrain the theoretically indeterminate process of legal interpretation. Although legal texts are always subject to multiple readings, institutionalists would predict that the structuration of the legal field will generate a stabilizing framework of norms and assumptions regarding what counts as a good, wise or subtle interpretation -and what is seen, instead, as a crass, mercenary, or overreaching political maneuver. ${ }^{81}$ Thus, greater attention to law as an organizational field promises to reveal important linkages between the study of legal interpretation and the study of the legal profession. ${ }^{82}$

Like the notion of the organizational field, the concept of the national polity also represents an effort to come to terms with the forces generating consistency among the various components of institutionalized rule systems. Here, however, the rule systems in question operate at the level of whole societies, rather than at the level of societal sectors. Thus, for example, in their ambitious and provocative essay, Jepperson and Meyer (ch. 9) ${ }^{83}$ argue that modern rationalized polities vary along two core dimensions: First, some polities endow subsocietal entities (individuals, professions, ethnic groups, etc.) with autonomous sovereign capacity, while others treat the collectivity itself as the primary bearer of social purpose, with smaller-scale entities participating only as functionaries and dependents. Second, some polities centralize collective control of societal functions and endeavors, while others see macro order as merely an epiphenomenal outgrowth of more spontaneous local activity. Using this cross-classification, Jepperson and Meyer identify four distinct polity types ("statist," "corporatist," "individualist," and "segmental/state-outside-society"), each with its own organizing logic. While one might disagree with this specific typology, the implications for sociolegal studies are certainly intriguing: By identifying common polity types, one might be able to describe and predict trajectories of legal change, in a manner far more powerful (and falsifiable) than most theories of comparative law currently allow. ${ }^{84}$

Admittedly, studies of regulatory regimes are only in their infancy within Institutional Theory, and many substantial gaps remain. In particular, institutional theorists have only recently begun to devote sustained attention to questions of how regimes emerge, how coherent normative and

81. See, e.g., Joseph R. Grodin, In Purstit of Justice: Reflections of a State Supreme Court Justice (Berkeley: University of California Press, 1989) ("Grodin, In Putsuit of Justice"); Karl N. Llewellyn, "The Normative, the Legal, and the Law-Jobs: The Problem of Juristic Method," 49 Yale L.J. 1355-400 (1940); id., "What Price Contract? An Essay in Perspective," in Lawrence M. Friedman \& Stewart Macaulay, eds., Law and the Behavioral Sciences (2d ed. Indianapolis: Bobbs-Merrill, 1977).

82. Cf. Peter Harris, "Ecology and Culture in the Communication or Precedent among State Supreme Courts, 1870-1970," 19 Law \& Soc'y Rev' 449 (1985).

83. Jepperson \& Meyer, "Public Order," New Institutionalism.

84. See, e.g., Elizabeth Heger Boyle, "Lawyers, Litigants, Legislators: Explaining Crossnational Variation in Legal Activity" (presented at American Sociological Association annual meeting, Washington, D.C., 1995). 
cognitive structures develop, and how jurisdictional boundaries solidify. ${ }^{85}$ Even less has been done to describe how rule systems acquire internal inconsistencies or how regimes fragment and fail. While Friedland and Alford's pathbreaking essay on "institutional contradictions" 86 points the way toward a deeper analysis of how multiple institutional logics may uneasily coexist within a single social setting, many crucial issues still remain unaddressed. Nonetheless, the existing institutional literature makes a promising start, and a close reading of its arguments could reenergize sociolegal research into the forces producing consistency and contradiction, determinacy and innovation, in the law. Ultimately, great legal struggles often boil down to disputes over institutional jurisdiction, and an understanding of societal sectors, national polities and institutional logics could provide useful handholds on the slippery slopes of legal change. ${ }^{87}$

\section{LESSONS FOR INSTITUTIONAL THEORY FROM LAW AND SOCIETY}

Clearly, institutional theory has much to offer to the Law and Society tradition. However, institutional theory may have much to learn from the Law and Society tradition as well. Indeed, upon delving into the institutional literature, sociologists of law are likely to experience an awkward sense of déjà vu. While institutional theorists are quite elegant and subtle in their treatment of organizational rule following, they often lack a similar subtlety in their treatment of rules themselves. Nowhere is this more true than in the case of official law, where the institutionalist outlook often comes uncomfortably close to naive Legal Formalism. Laws mean what they say, and they do what they mean; institutional analysis is simply a matter of delineating how these clear-cut constraints transform the organizational environments that they govern.

85. But see Walter W. Powell, "Expanding the Scope of Institutional Analysis," New Institutionalism; DiMaggio, "Constructing an Organizational Field," and Brint \& Karabel, "Institutional Origins and Transformations," New Institutionalism (both cited in note 31); and Brint \& Karabel, Diverted Dream (also cited in note 31). 37).

86. Friedland \& Alford, "Bringing Society Back In," New Institutionalism (cited in note

87. Readers who doubt the role of competing institutional logics in legal history might wish to consider the following litany from Friedland and Alford:

Some of the most important struggles between groups, organizations and classes are over the appropriate relationships between institutions, and by which institutional logic different activities should be regulated. . . . Are families, churches or states to control education? Should reproduction be regulated by state, family or church? . . . Does equal protection apply to competition in the labor market? . . . Do the rights of citizenship apply to the economy or do those of the market apply to the state? . . . Although these struggles are acted out by groups and organizations, their consequences alter the interinstitutional relations constituting a society.

Friedland \& Alford, "Bringing Society Back In," New Institutionalism 256 (cited in note 37). 
Thus, for example, DiMaggio and Powell (ch. 3) illustrate their archetype of "coercive isomorphism" with the observation: "In some circumstances, organizational change is a direct response to government mandate: manufacturers adopt new pollution control technologies to conform to environmental regulations; non-profits maintain accounts and hire accountants in order to meet tax law requirements; and organizations employ affirmative action officers to fend off allegations of discrimination." ${ }^{88}$ Similarly, Scott (ch. 7) links the most direct and unambiguous form of institutional influence (the "imposition" of organizational structure) to the operation of formal law, noting: "Some sectors or fields contain environmental agents that are sufficiently powerful to impose structural forms on subordinate organizational units. Nation-states do this when mandating by law changes in existing organizational forms." ${ }^{\text {" F }}$ Fligstein (ch. 13), too, expresses this formalist presumption when he argues: "the state can actually set the rules of the game for any given organizational field .... It can, therefore, alter the environment more profoundly and systematically than other organizations." 90 Although institutionalist writings (including those cited here) contain other passages expressing more qualified views of legal constraint, the baseline assumption seems to be that laws are explicit, authoritative, and coercive-at least until proven otherwise.

From the perspective of the Law and Society tradition, this emphasis on the formal dictates of the law has several weaknesses. By treating law as explicit, institutional theory obscures the extent to which law is, in reality, obscure, fragmented and highly ambiguous: Since the earliest days of the Law and Society movement, research has consistently found that law-inaction reflects a crazy-quilt of pluralistic normative orders and overlapping regulatory jurisdictions. Further, by treating law as authoritative, institutional theory obscures the extent to which law is, in reality, malleable, contested, and socially constructed: Not only do organizations occasionally "capture" the law and shape it to fit their own interests, ${ }^{11}$ but also organizations often "enact"92 the meaning of the law through a complex, largely inadvertent cycle of action, mimicry, and interpretation. ${ }^{93}$ Finally, by treating law as coercive, institutional theory obscures the extent to which law is, in reality, symbolic, discursive, and constitutive: Although legal environ-

88. DiMaggio \& Powell, "Iron Cage Revisited," New Institutionalism 67.

89. W. Richard Scott, "Unpacking Institutional Arguments," New Institutionalism 175.

90. Fligstein, "Structural Transformation of American Industry," New Institutionalism 314 (cited in note 31 ). 49).

91. Clune, 69 Iowa L. Rev.; Hawkins, Environment and Enforcement (both cited in note

92. Karl E. Weick, The Social Psychology of Organizing (Reading, Mass.: Addison-Wesley, 1979) ("Weick, Social Psychology of Organizing").

93. See, e.g., Vicki Eaton Baier, James G. March, \& Harald Saetren, "Implementation and Ambiguity," in James March, ed., Decisions and Organizations (Oxford: Basil Blackwell, 1988) ("Baier et al., "Implementation"'); Teresa L. Scheid-Cook, "Organizational Enactments and Conformity to Environmental Prescriptions," 45 Human Relations 537 (1992). 
ments exert pressure on organizations, they do so primarily by redefining the normative value of old practices or by creating the cognitive building blocks for new ones, rather than by applying substantive penalties in strict accordance with specific sovereign edicts. In short, although institutional analysis far surpasses previous organizational theories in its attentiveness to societal rule systems, constitutive definitions, and categorical constraints, its conception of law seems oddly sterile and formalistic.

Admittedly, neither ambiguity nor social construction nor constitutive symbolism represent alien concept within institutional theory as a whole. To date, however, such terms have rarely found their way into institutional discussions of the legal order per se. For this reason, legal rules often seem to hold less interest for institutionalists than the informal norms of professions or the informal standards of industries. The law, in institutional analysis, often retreats to the status of a global background constraint or a timeperiod dummy variable. ${ }^{94}$ Perhaps, however, if institutionalists attended more carefully to the lessons of the Law and Society tradition, they might find the law to be a rich, fluid, and complex institutional arena, worthy of sustained empirical and theoretical attention in its own right. In contrast to the dominant imagery in organizational studies, sociologists of law see the legal realm as a world of folly, flux, ambiguity, bias, manipulation, struggle, symbolism and ideology-a world every bit as complex and dynamic as the societal sectors and formal organizations that the law supposedly regulates.

A single essay could hardly explore all of the intricacies that Law and Society scholars have documented or hypothesized. As suggested above, however, at least three departures from the Legal Formalist model are sufficiently well established and sufficiently organizationally relevant to merit comment here: First, law is often uncertain, not determinate; second, law is often contested, not authoritative; and third, law is often constitutive, not coercive.

\section{Law as Uncertain and Ambiguous}

Law and Society research points to at least three distinct characteristics of law that render it uncertain rather than determinate: legal ignorance, legal pluralism, and legal ambiguity.

\section{Legal Ignorance}

When addressing the impact of legal rules on organizational behavior, institutional theorists generally assume that organizations know what the law is. Law and Society research, however, suggests that this superficially

94. See, e.g., Fligstein, "Structural Transformation of American Industry," New Institutionalism; Tolbert \& Zucker, 28 Admin. Sci. Q. (cited in note 7). 
plausible assumption may be seriously flawed. Legal systems have no automatic mechanism for disseminating information about law, and formal legal publications are accessible only to those with the inclination and skill to find them. People learn lessons about the law from the media, the professions, the educational system, and first-hand experience; however, these lessons are rarely very accurate, detailed, or complete. ${ }^{95}$ Although the legal profession may help laypeople to "find the law," lawyers themselves generally remember legal rules primarily as aphorisms and rules-of-thumb, and attorneys' casual legal opinions may be no more reliable than those of their clients. ${ }^{96}$ Moreover, studies of corporate criminality report that organizations frequently delegate the task of "knowing the law" to their legal departments-and then intentionally freeze those departments out of corporate decision making. ${ }^{97}$ In short, organizations give the law, like other facets of their environments, only selective and imperfect attention, at best. ${ }^{98}$

\section{Legal Pluralism}

When "law" does impinge on the perceptions of organizational decision makers, there is no guarantee that it will be the formal, public law of the nation-state. As Macaulay has noted, sociolegal scholars recurrently report: "Many of the functions usually thought of as legal are performed by alternative institutions, and there is a great deal of [interpenetration] between what we call public and private sectors. ... Trade associations, sports leagues, church groups, neighborhood organizations and many other 'private' units . . . exercise what are, effectively, legal powers." 99 At times, the state will actually grant the full force of law to these local regimes; however, even when the state retains formal authority, local gossip and ostracism generally supplant official legal penalties as the primary sanctions in most com-

95. Robert L. Kidder, Connecting Law and Society (Englewood Cliffs, N.J.: Prentice-Hall, 1983); Stewart Macaulay, "Images of Law in Everyday Life: The Lessons of School, Entertainment, and Spectator Sports," 21 Law \& Soc'y Rev. 185 (1987); Marc Galanter, "The Civil Jury as Regulator of the Litigation Process," 1990 U. Chi. Legal F. 201 (1990); Lauren B. Edelman, Steven E. Abraham, \& Howard S. Erlanger, "Professional Construction of the Legal Environment: The Inflated Threat of Wrongful Discharge Doctrine," 26 Law \& Soc'y Rev. 47 (1992).

96. Robert A. Kagan \& Robert E. Rosen, "On the Social Significance of Large Law Firm Practice," 37 Stan. L. Rev. 399 (1985); Robert C. Ellickson, "Of Coase and Cattle: Dispute Resolution among Neighbors in Shasta County," 38 Stan. L. Rev. 623 (1986).

97. Stone, Where the Law Ends (cited in note 48).

98. Cf. Weick, Social Psychology of Organizing; James G. March, "Decisions in Organizations and Theories of Choice," in Van de Van \& Joyce, Perspectives (cited in note 39); ScheidCook, 45 Hum. Rel.

99. Stewart Macaulay, "Law and the Behavioral Sciences: Is There Any There There?" 6 Law \& Pol'y 149, 152-53 (1984). 
munities-including most organizational communities. ${ }^{100} \mathrm{~A}$ corollary to this pervasive legal pluralism is the finding that formal rules are, themselves, transformed by the local communities of regulators and regulateds that must implement them-communities that may differ dramatically from one locale to another. ${ }^{101}$

\section{Legal Ambiguity}

As telling as these insights may be, however, they only scratch the surface of the critique of Legal Formalism. To talk of "legal ignorance" or "legal pluralism" is to dispute the penetration of law while granting law's existence as an objective reality. Yet, the most problematic aspect of claiming that organizations "know what the law is" may be the embedded assumption that the law "is" a single knowable, determinate thing. Law and society scholarship shows that "the Law" is actually a welter of conflicting principles, imperfect analogies, and ambiguous generalities. Thus, lawyers, judges, enforcers, and target populations negotiate the meaning of law in each application, seeking workable consensus rather than logical certainty. ${ }^{102}$ As noted above, institutional processes often generate tacit agreements about the contents of legal mandates and about the standards of legal interpretation; nonetheless, a shared convention is not really the same thing as an objective meaning, and at some level, every application of law remains fundamentally an exercise in social creativity. Contrary to the casual assertions of institutional theorists, it is simply untrue that organizations "can only be in compliance or not in compliance with specific regulations." 103

Given these observations, law may be best conceptualized not as an objective external constraint but rather as a source of uncertainty in organizational life. New laws (and often the processes leading up to new laws) alert organizations to the possibility that the institutional environment may have changed. In itself, however, this alarm does little to clarify the nature or the extent of that change. Rather, the passage of a law provides an occasion for the collective construction of compliance. ${ }^{104}$ Legal shifts accelerate

100. Indeed, in many settings, the highest crime under the informal law is an overzealous use of the formal law. See, e.g., Macaulay, $28 \mathrm{Am}$. Soc. Rev. (cited in note 10); Ellickson, 38 Stan. L. Rev.

101. See, e.g., Sally Falk Moore, "Law \& Social Change: The Semi-autonomous Social Field as an Appropriate Subject of Study," 7 Law \& Soc'y Rev. 719 (1973); Gregory Massell, "Law as an Instrument of Revolutionary Change in a Traditional Milieu: The Case of Soviet Central Asia," 2 Law \& Soc'y Rev. 179 (1969).

102. See, e.g., Paul Burstein, "Intergroup Conflict, Law, and the Concept of Labor Market Discrimination," 5 Soc. F. 459 (1990); Edelman, 97 Am. J. Soc. (cited in note 2); Blumrosen, Modern Law (cited in note 1).

103. Meyer, "Institutionalization and the Rationality of Formal Organizational Structure," in Meyer \& Scott, Organizational Environments (cited in note 22).

104. Edelman, 97 Am. J. Soc. 
sense-making efforts, ${ }^{105}$ spawn decision events, ${ }^{106}$ spark search activity, ${ }^{107}$ and stimulate mimesis. ${ }^{108}$ Eventually, these efforts may produce a tentative working agreement on what the law "is" and what it "requires." This meaning, however, is an endogenous product of historical social interactions; it is not an exogenous characteristic of specific words on a piece of paper.

\section{Law as Political and Contested}

Few institutional theorists would dispute the contention that laws (particularly statutory laws) emerge from a political process. However, a healthy skepticism about the instrumentalism of politics ${ }^{109}$ and a predilection for treating the law as exogenous lead institutionalists to see legal rules as neutral and authoritative, once those rules have been formally enacted. In contrast, Law and Society research stresses that the law is thoroughly and unrelentingly political, not only in its enactment but also in its interpretation and application. Courts, enforcement agencies, lawyers, and target populations themselves all act as filtering agents, each possessing the capacity to transform the meaning of the law and the definition of compliance, in accordance with partisan interests and ideologies. Over time, these political constructions become institutionalized in social practice and, often, embraced in judicial opinions. Organizations play a major role in this process, and institutional theorists would do well to consider how organizations mediate, not just respond to, law.

\section{The Politics of Legal Enforcement}

Perhaps the most obvious locus of postlegislative politics lies in the regulatory agencies chartered to "enforce the law." According to the imagery of Legal Formalism, these agencies act only within the scope of their official charter; but within that limited purview, they use the full force of authorized legal sanctions to pursue universal compliance with clear statutory goals. This formalist outlook is often echoed in institutional accounts of regulatory enforcement, such as Fligstein's (ch. 10) assertion that: "The

105. Weick, Social Psychology of Organizing (cited in note 92); cf. Stephen R. Barley, "Technology as an Occasion for Structuring: Evidence from Observations of CT Scanners and the Social Order of Radiology Departments," 31 Admin. Sci. Q. 78 (1986).

106. Michael D. Cohen, James G. March, \& John P. Olsen, "A Garbage Can Model of Organizational Choice," 1 Admin. Sci. Q. 1 (1972).

107. Richard M. Cyert \& James G. March, A Behavioral Theory of the Firm (Englewood Cliffs, N.J.: Prentice-Hall, 1963).

108. DiMaggio \& Powell, "Iron Cage Revisited," New Institutionalism.

109. See, e.g., Jepperson \& Meyer, "Public Order," New Institutionalism 227 (cired in note 38) ("In sociological analyses, the term power is commonly used to refer to authority that the analyst wishes to delegitimate"); see also Friedland \& Alford, "Bringing Society Back In," New Institutionalism 242 ff. (cited in note 37). 


\section{LAW AND SOCIAL INQUIRY}

[Celler-Kefauver Act] was applied constantly and consistently . . . throughout the 1950s and 1960 s. . . . The state thus changed the rules by which firms could expand." 110

In contrast, Law and Society scholarship suggests that legislative ambiguity and administrative politics often result in statutory "mandates" that either provide little regulatory guidance or demand impossible regulatory results, or both. ${ }^{111}$ This means that as a practical matter, administrative agencies enjoy a great deal of discretion, and regulators can become politicized both on the basis of their substantive policy preferences and on the basis of internal bureaucratic agendas. ${ }^{112}$ Further, faced with constrained budgets and weakly conceptualized compliance measures, enforcement agents look for easily observable symbols of compliance, instead. ${ }^{113}$ Regulated organizations, for their part, willingly collaborate in constructing symbolic criteria that meet the needs of regulators without fundamentally disrupting the established routines of the targeted sector. ${ }^{114}$

Each of these departures from the formal model makes regulation look less like top-down coercion and more like bottom-up cooptation. Far from imposing external constraints on passive recipients, regulation often seems to institutionalize the indigenous practices of the regulated population. ${ }^{115}$ At the extreme, agencies can become captives of the industries that they oversee-either through direct domination or, more commonly, through a subtle ideological convergence born of repeated contact, regular interaction and pervasive personnel exchange. Thus, the Law and Society tradition suggests that regulation is neither neutral nor exogenous. Rather, the law is made as it is enforced, often with as much input from those who are its targets as from those who are its custodians.

\section{The Politics of Organizational Response}

Although the politics of enforcement have received the most extensive attention from sociolegal researchers, the regulatory arena is not the only context in which political action filters the impact of law. In day-to-day

110. Fligstein, "Structural Transformation of American Industry," New Institutionalism 321 (cited in note 31 ).

111. Clune, 69 Iowa L. Rev. (cired in note 49); Hawkins, Environment and Enforcement (cited in note 49); Baier et al., "Implementation" (cited in note 93); Blumrosen, Modern Law (cired in note 1 ).

112. Indeed, one plausible way to understand ambiguous statutes is as devices for overcoming legislative contention by implicitly allowing each side to "make a bet" on the outcome of subsequent interpretation. This technique has the political appeal of permitting the ultimate loser to plead good intentions and to decry the sorry perversion of "legislative intent."

113. Hawkins, Environment and Enforcement.

114. Edelman, $97 \mathrm{Am}$. J. Soc. (cited in note 2).

115. Clune, 69 Iowa L. Rev; Edelman, 97 Am. J. Soc.; Edelman et al., "Endogeneity" (cited in note 43). 
organizational life, the inherent ambiguity of the law creates room for manipulation, interpretation, and enactment on the part of actors both within and outside of organizations. By imposing threatening uncertainties on organizational operations, new laws create political opportunities for those internal and external entities that can plausibly claim to manage such uncertainties. Indeed, the social construction of legal threat can become a primary vehicle by which individuals, subunits, and professions advance their own status and prestige. Thus, for example, Edelman et al. report that the risk of wrongful discharge suits has been systematically exaggerated by personnel professionals, who have offered their own services as an inoculation against this largely fictitious plague. ${ }^{116}$ Along similar lines, one might speculate about whether the risks of the Celler-Kefauver Act were, to some extent, socially constructed by financial officers, who could offer diversified portfolio management as, in Fligstein's words (ch. 10), "the only option left for growth." 117 While the truth of this speculation remains to be seen, it illustrates the ability of Law and Society principles to reframe institutional theory questions.

Analogous political dynamics may operate in the external environments of targeted organizations, as well. In this regard, Suchman describes the influence that law firms, acting as "interorganizational pollinators," exerted on venture-capital financing practices in Silicon Valley. ${ }^{118}$ As the new industrial community emerged, lawyers acted first to transmit norms and typifications among otherwise isolated clients, then to formulate and sponsor a variety of competing prescriptions for practice, and ultimately to export the emerging "Silicon Valley model" beyond the community's borders. Rather than taking national securities laws as exogenous constraints, lawyers in Silicon Valley actively constructed a local regime that eventually reshaped a substantial portion of the larger system.

The message from all these studies is that legal ambiguity opens the door for political manipulation, selective enactment and self-serving interpretation. To some extent, such activities presumably stem from instrumental calculations on the part of various affected interests. Nonetheless, institutional theory could easily incorporate Law and Society insights on the politics of law while retaining a healthy skepticism about the rationality of organizational action. The primary Law and Society contention is simply

116. Edelman et al., 26 Law \& Soc'y Rev. (cited in note 95). Of course, such prescriptions are likely to become self-fulfilling prophecies, as "modern" personnel practices come to be seen by both employees and regulators as evidence of an employer's genuine concern for equal opportunity.

117. Fligstein, "Structural Transformation of American Industry," New Institutionalism 321; cf. R.R. Ritti \& Fred H. Goldner, "Professional Pluralism in an Industrial Organization," 16 Management Sci. 233-34 (1979).

118. Suchman, "On Advice of Counsel" (cited in note 3); id., "Localism and Globalism in Institutional Analysis: The Emergence of Contractual Norms in Venture Finance," in Scott $\&$ Christensen, Institutional Construction (cited in note 43). 
that people in different social locations apply and interpret the law differently. At times, these biases may reflect a calculated collective strategy; however, at other times, they will simply embody the accumulated impact of facially trivial routines ${ }^{119}$ or the framing effects of sincerely held ideologies. Cognitive institutionalists would probably emphasize the extent to which the "political" activities described above involve communities struggling to make sense of their social worlds, rather than the extent to which such activities involve factions scheming to take advantage of one another. ${ }^{120}$ In itself, however, this observation does not render the processes of enforcement and interpretation apolitical -or at least it does not render them any less political than the process of legislation itself.

\section{Law as Symbolic and Constitutive}

A persistent problematic in the Law and Society tradition is the effort to reconcile legal ignorance, legal pluralism, and legal ambiguity with a sense that law matters-that it is worth the political energy devoted to contesting it. ${ }^{121}$ This tension, of course, becomes largely invisible if one assumes that law is explicit, authoritative, and coercive. Yet, such simplifying assumptions also obscure important ways in which law can shape social life without directly imposing specific behaviors. In particular, the reification of law as a set of instrumental coercive edicts obscures the extent to which law is, in reality, a set of constitutive and transformative symbols.

\section{Law as Constitutive}

Recent Law and Society scholarship-especially in the Critical Legal Studies camp ${ }^{122}$ - has increasingly come to see law as operating to constitute social life, rather than to regulate it. Even when actors lack the specific legal knowledge required for effective deterrence, they may nonetheless incorporate general legal categories into their cognitive maps, allowing the law to frame and constrain perceptions of the world. At the most superficial level, law provides a ready-made justification for conformity, helping individuals and organizations to address conflicting cultural demands that their actions be simultaneously rational, moral and predictable. More profoundly,

119. E.g., Marc Galanter, "Why the 'Haves' Come Out Ahead: Speculations on the Limits of Legal Change," 9 Law $\mathcal{E}^{2}$ Soc'y Rev. 95 (1974).

120. See, e.g., Friedland \& Alford, "Bringing Society Back In," New Institutionalism (cited in note 37 ).

121. Cf. Macaulay, 6 Law \& Pol'y at 149-87 (cited in note 99).

122. E.g., Duncan Kennedy, "Toward an Historical Understanding of Legal Consciousness: The Case of Classical Legal Thought in America, 1850-1940," 3 Res. L. E Soc. 3 (1980); Gabel, 3 Res. L. $\mathcal{E}$ Soc. (cited in note 5); Robert W. Gordon, "Critical Legal Histories," 36 Stan. L. Rev. 57-125 (1984); Boyle, 133 U. Pa. L. Rev. (cited in note 13). 
law establishes a taken-for-granted categorical structure for social relations-and provides a set of accepted rituals for manipulating that structure. Law (or, more precisely, the socially constructed interpretation of law) tells us what is and isn't property, who is and isn't an employee, what is and isn't a corporation. Moreover, law establishes procedures for transferring property, hiring employees, and forming corporations, and law makes these procedures efficacious by definition. In keeping with the arguments outlined above, all these categories and procedures remain ambiguous and contested at the margins; however, this does not detract from the fact that their integration into the legal order effectively reifies and "naturalizes" their existence, their relevance, and their core content. ${ }^{123}$ While organizations can (and do) dispute whether freelance workers are "employees," they rarely dispute the meaningfulness of the concept of employment or the fact that it has something to do with an exchange of labor for money.

\section{Law as Transformative}

Not only does law provide a symbolic framework for comprehending social relations, it also provides symbolic resources for transforming them. Because the law cultivates an aura of objectivity, universality, and neutrality, the legal system can serve as a potent force for reifying and institutionalizing emerging social conventions. ${ }^{124}$ In common law litigation, for example, the legal system produces a series of morality plays that reenact, and thus reinforce, beliefs about goodness, truth, fairness, and equality. ${ }^{125}$ Each of these morality plays ceremonially introduces a highly stylized "problem situation" into the public discourse, and each offers up a "just" resolution. The stream of cases may reflect structural biases of the forum, ${ }^{126}$ and the stream of resolutions may reflect interpretive biases of the adjudicators. ${ }^{127}$ However, by embracing the symbolic trappings of procedural and distributive justice, the

123. Cf. Mary Douglas, How Institutions Think (Syracuse, N.Y.: Syracuse University Press, 1986).

124. This may be particularly true during periods of radical sociopolitical realignment, such as the break-up of the Eastern Bloc or the formation of the European Community. When society's normative order is in turmoil, the purported objectivity and universality of the law can serve as a crucial symbolic seed for reestablishing shared meanings. Disparate local communities may not agree on the content of specific legal rules; however, if they can agree that certain rules exist, and that those rules can, in theory, be comprehended and obeyed, that is a start.

125. Mark C. Suchman, "Un-trashing the Garbage Can: The Case of the Common Law" (presented at Stanford Conference on Organizations at Asilomar, Pacific Grove, Cal., 1990).

126. Galanter, 9 Law \& Soc'y Rev.; id., "Case Congregations and Their Careers," 24 Law \& Soc'y Rev. 371-95 (1990).

127. Grodin, In Pursuit of Justice (cited in note 81). 
legal system makes these biases hard to identify and harder still to articulate. ${ }^{128}$

The legal system provides transformative symbolic resources in the enforcement process as well. Not only do enforcers often accept symbolic conformity in place of substantive compliance, but, more profoundly, the importance of clear categories and bright-line rules in the law actually legitimizes ceremonialism. A standard that might, at first, be nothing more than a convenient regulatory rule-of-thumb becomes, over time, the legal definition of good behavior; formal criteria drive out substantive objectives. More generally, law provides regulators (and their constituents) with significant cognitive leverage to reconstitute organizational environments and to reframe environmental demands. By shaping conceptions of the possible and the desirable, law shapes what is expected of organizations and what is required. And by shaping conceptions of the normal and the aberrant, law shapes what is mimicked by organizations and what is ignored.

In short, law is much like other elements of organizations' institutional environments: not an explicit, authoritative and coercive system of material constraints, but an ambiguous, contested, and constitutive system of cultural understandings. The New Institutionalism has taken great strides in bringing law into the organizational picture, but the lessons of sociolegal scholarship call for more careful attention to the law's pervasive informalism and malleability.

\section{TOWARD RECIPROCALITY BETWEEN LAW AND ORGANIZATIONS}

The informalism of law, together with the cultural character of organizations, creates room for a dynamic interplay between the two arenas. Each helps to constitute the other. On the one side, New Institutionalists argue that societal rules enter organizational life not only as adjustments to the costs and benefits of specific instrumental behaviors but also as pervasive normative and cognitive frameworks for the social construction of reality. On the other side, Law and Society scholars argue that legal rules not only reconstitute organizations but are often reconstituted by organizations as well. Viewed together, the two traditions suggest that the relationship between organizations and their legal environments is a highly endogenous and reciprocal one.

This reciprocality between law and organizations appears at the intraorganizational, organizational, and environmental levels. At the intraor-

128. Eugene D. Genovese, Roll Jordan Roll (New York: Pantheon Books, 1976); Tyler \& Lind, Social Psychology of Procedural Justice (cited in note 38). 
ganizational level, different portions of the organization come in contact with (and are constituted by) different portions of the legal world. As a result, most organizations exhibit considerable internal legal pluralism. With the ambiguities and contradictions of the larger legal order mapped onto intraorganizational structure, subunit politics are likely to play a significant role in determining the import of legal constraint: ${ }^{129}$ At times, political processes within the organization will exclude particular legal considerations from organizational decision-making. In these situations, if the organization's legal staff can successfully manage external challenges to organizational actions, the law will matter little. At other times, however, political considerations will move certain camps within the organization to portray a particular legal threat as uniquely fearsome or to portray a particular solution as uniquely effective. ${ }^{130}$ If the organization acts on these alarms, and if others organizations imitate its actions, the standards for compliance in the organizational field are likely to strengthen, and the law may matter more than the rules on paper would suggest.

At the organizational level of analysis, organizations reciprocally define the law through their practices regarding compliance. Responsive to their cultural environments, organizations often voluntarily seek to comply with legal change. However, the socially constructed nature of legal constraint implies that these efforts, themselves, can mold the meaning of the mandate. Courts frequently measure compliance against "industry standards" or "business necessity" or "the limits of current technology," and all these yardsticks, in one way or another, embody the institutionalized expectations of the organizations supposedly being regulated. Further, courts almost never formulate potential solutions sua sponte; judicial opinions may identify which existing responses are acceptable and which are not, but judges rarely demand new options that did not appear previously somewhere within the target population. ${ }^{131}$ Thus, the demands of the law can never be entirely separated from the processes by which particular organizations define for themselves what is possible, normal, and desirable.

The role of prevailing industry practices in this criterion-setting process blends naturally into the third, environmental, level of reciprocality between organizations and law. Since all legal pronouncements are at least somewhat indeterminate, the solidification of the law often hinges on the emergence of local standards-both standards of practice and standards of interpretation. The speed at which such standards emerge, and their stability once in place, depends quite intimately on the structure of communica-

129. Cf. Weick, Social Psychology of Organizing (cired in note 92).

130. Edelman et al., 26 Law \& Soc'y Rev. (cited in note 95).

131. Even when courts independently evaluate a law, they often base their assessment on the prior history of regulatory action (e.g., administrative "letter rulings")-a history which may, itself, reflect constructions of law negotiated between tegulators and members of the regulated industry. 
tion channels in the interorganizational environment. For this reason, sectors characterized by professional networks, trade publications, and intermediary organizations are likely to experience the law as far more concrete and binding than sectors lacking such features. ${ }^{132}$ In the final analysis, legal meanings are products of local discourses, not of sovereign edicts. Consequently, the structure of the law is likely to reflect the structure of interorganizational information flows-far more than it reflects the structure of legislative policy debate.

\section{CONCLUSION: INSTITUTIONS IN ACTION}

This essay suggests a number of lessons for both the Law and Society tradition and institutional theory. Its primary thrust, however, is to urge researchers from each camp to remain true to their own best instincts, even when they are wandering beyond their traditional intellectual domains. At their cores, the two traditions have a great deal in common. Both the Law and Society movement and the New Institutionalism trace their roots back to Max Weber's writings on "legal rationality." Both have also increasingly emphasized that this term describes a socially constructed cultural mythology, not an objective reality of seamless rules and optimal decisions. Unfortunately, the farther one strays from one's home turf, the more vulnerable one becomes to the lure of objectivizing simplifications. Although the Law and Society tradition has formulated a sophisticated constructionist account of legal constraint and response, it retains a deterministic, instrumental treatment of organizations. Similarly, although institutional theory has formulated a sophisticated constructionist account of organizational behavior, it retains a deterministic, instrumental treatment of law. In contrast, the fundamental claim of the preceding pages is that organizations are very much like other subjects of the legal system and that laws are very much like other rules in the organizational environment.

This insight opens substantial new vistas both for sociolegal studies and for institutional analysis. If organizations are like other subject populations, then one need no longer assume that organizations will inevitably exploit and evade the law. Instead, one can seriously explore the complex ways in which laws may shape organizations' normative commitments and may constitute organizations' cognitive assumptions. Conversely, if laws are like other rule systems, then one need no longer assume that laws will inevitably coerce and impose organizational isomorphism. Instead, one can seriously explore the complex ways in which organizations may mediate the impact of

132. See, e.g., Suchman, "On Advice of Counsel" (cite in note 3); Ryken Grattet, "Coalition and Conference: Social Networks and the Structuration of an Organizational Field" (Dep't of Sociology, Louisiana State University, 1995). 
legal mandates and may construct the meaning of legal compliance. Together, these explorations promise a richer understanding of symbolic conformity and a more complex conception of legal impact.

Significantly, however, the true value of such an exchange between organizational and legal scholars may extend beyond merely refining their treatments of law and organizations, respectively. Rather, in expanding the dialogue between these two kindred traditions, theorists in each camp are likely to discover pervasive affinities between their own intellectual efforts and the endeavors of their colleagues on the other side of the divide. We have already noted that Law and Society scholarship might profit from examining the recent work that institutional theorists have done on individual action and regulatory regimes. Along similar lines, institutional theory might benefit greatly from a close reading of the recent work that sociolegal scholars have done on the interplay between formal rules and informal practices. Traditionally, institutionalists have been satisfied to treat even nonlegal rules as relatively clear and agreed upon, albeit perhaps lacking the ostensible coercive force of the law. Yet, if the formal law itself is actually ambiguous, negotiated, and reciprocally constitutive in its relationship to social life, it stands to reason that other rule systems may be as well. At some level, institutional theory has already begun to acknowledge this possibility, particularly in discussions of the relationship between organizations, professions, and markets. ${ }^{133}$ However, institutional theorists are still several steps behind their Law and Society colleagues in wrestling with these complex issues. In this as in other areas, greater mutual awareness between the Law and Society tradition and the New Institutionalism promises an improved understanding of the complex ways in which institutional rule systems are constructed and mediated by day-to-day organizational life-an understanding, one might say, of "institutions-in-action."

133. Sèe, e.g., DiMaggio, "Constructing an Organizational Field," New Institutionalism, Brint \& Karabel, "Institutional Origins and Transformations," New Institutionalism, and Galaskiewicz, "Making Corporate Actors Accountable," New Institutionalism (all cited in note 31). 
HeinOnline -- 21 Law \& Soc. Inquiry 9421996 


\section{Rethinking Social Control}

John R. Sutton

Walter W. Powell and Paul J. DiMaggio, eds. The New Institutionalism in Organizational Analysis. Chicago: University of Chicago Press, 1991.

In the contemporary sociolegal literature, few concepts are invoked more frequently, and with less clarity of meaning and purpose, than that of social control. The ambiguity of the concept is due in large part to its circuitous historical provenance. ${ }^{1}$ The early Chicago sociologists coined the term to signify the interpersonal foundations of the self and social order. ${ }^{2}$ Parsons synthesized it with elements of Durkheim and Freud as a central component of his social systems theory: Social control in his view was not just an interactional process, but a structural sine qua non of a healthy society. ${ }^{3}$ Partly in reaction to the smugness of the Parsonsian model, labeling theorists hewed closer to the original Chicago interpretation and gave the concept a critical spin by emphasizing the iatrogenic nature of much deviant behavior ${ }^{4}$ and by arguing that social control is not a systematic imperative but rather a construction of self-interested "moral entrepreneurs." More recent critical scholars-a category that includes a wide range of theoretical perspectives,

John R. Sutton is a professor in the Department of Sociology, University of California, Santa Barbara.

1. Dario Melossi, The State of Social Control (New York: St. Martin's Press, 1990).

2. Edward A. Ross, Social Control (New York: MacMillan, 1901); George Herbert Mead, "The Genesis of the Self and Social Control," 35 Int'l J. Ethics 251 (1924-25); see also Gary G. Hamilton \& John R. Sutton, "The Problem of Control in the Weak State: Domination in the United States, 1880-1920," 18 Theory \& Soc'y 1 (1989).

3. Talcott Parsons, The Structure of Social Action (New York: McGraw-Hill, 1937); id., The Social System (Glencoe, Ill.: Free Press, 1951).

4. Erving Goffman, Asylums: Essays on the Social Situation of Mental Patients and Other Inmates (Garden City, N.Y.: Anchor, 1961); Edwin M. Lemert, Human Deviance, Social Problems, and Social Control (Englewood Cliffs, N.J.: Prentice Hall, 1967).

5. Howard Becker, Outsiders: Studies in the Sociology of Deviance (New York: Free Press, 1963); Joseph Gusfield, Symbolic Crusade (Urbana: University of Illinois Press, 1963); Kai T. Erikson, Wayward Puritans: A Study in the Sociology of Deviance (New York: John Wiley, 1966). 
from Marxian political economy to poststructuralism-use social control to signify a form of political domination in which the oppressed are reconciled to their own oppression. ${ }^{6}$

Critical theorists argued that the motor of social control is not benign societal imperatives but particularistic class-, race-, and gender-based interests. But in making this claim, they tended to reproduce the very tautology that proved fatal to Parsonsian functionalism: Too often they portrayed reformers and policymakers simplistically, as stooges of a backstage elite, and assumed, rather than demonstrated, that social control policies had the expected effects on individual lives. Their critique of whig history was long overdue, but the "social control hypothesis," as it came to be known, was widely criticized for its oversimplification and lack of agency. ${ }^{7}$ Other studies in the tradition of the "new social history" 8 have generated more complex analyses of the linkages between ideologies, policies, institutional practice, and individual outcomes. But this vein of research has not, as yet, given rise to an alternative theoretical perspective on social control. Indeed one of its major contributions is to question whether social control does, in fact, control.

6. This category is too broad and varied to permit more than an impressionistic listing. Classic statements of the Marxist position are found in Richard Quinney, Critique of Legal Order: Crime Control in Capitalist Society (Boston: Little, Brown, 1974). and Ian Taylor, Paul Walton, \& Jock Young, The New Criminology: For a Social Theory of Deviance (London: Routledge \& Kegan Paul, 1973); see Anthony M. Platt, The Child Savers: The Invention of Delinquency (Chicago: University of Chicago Press, 1969), for an empirical application that synthesizes Marxism with labeling theory. Important early statements of the feminist position include Marcia Millman, "She Did It All for Love: A Feminist View of the Sociology of Deviance," in Marcia Millman \& Rosabeth Moss Kanter, eds., Another Voice: Feminist Perspectives on Social Life and Social Science (Garden City, N.Y.: Doubleday-Anchor, 1975), and Susan Brownmiller, Against Our Will: Men, Women, and Rape (New York: Simon \& Schuster, 1975); for more recent statements see Loraine Gelsthorpe \& Allison Morris, "Feminism and Criminology in Britain," 28 Brit. J. Crim. 223 (1988), and Edwin M. Schur, Labeling Women Deviant: Gender, Stigma, and Social Control (New York: Random House, 1984). For studies bearing a poststructuralist influence-especially via Foucault-see Stanley Cohen, Visions of Social Control (Cambridge, Eng.: Polity Press, 1985); Nanette J. Davis \& Bo Anderson, Social Control: The Production of Deviance in the Modern State (New York: Irvington, 1983); David Garland, Punishment and Modern Society: A Study in Social Theory (Chicago: University of Chicago Press, 1990) ("Garland, Punishment"); Melossi, State of Social Control (cited in note 1); and Stephen Pfohl, Images of Deviance and Social Control: A Sociological History (New York: McGraw-Hill, 1994).

7. John Hagan, "The Legislation of Crime and Delinquency: A Review of Theory, Method, and Research," 14 Law \&ै Soc'y Rev. 603 (1980); Michael Ignatieff, "State, Civil Society and Total Institution: A Critique of Recent Social Histories of Punishment," in Michael Tonry \& Norval Morris, eds., 3 Crime and Justice: An Annual Review of Research (Chicago: University of Chicago Press, 1981); Robert M. Mennel, "Attitudes and Policies toward Juvenile Delinquency in the United States: A Historiographical Review," 4 Crime $\mathcal{E}$ Just. 191 (1983); David J. Rothman, "Social Control: Uses and Abuses of the Concept in the History of Incarceration," in Stanley Cohen \& Andrew Scull, eds., Social Control and the State (New York: St. Martin's Press, 1983).

8. E.g., E. P. Thompson, Whigs and Hunters: The Origin of the Black Act (New York: Pantheon, 1975); Michael B. Katz, Poverty and Policy in American History (New York: Academic Press, 1983); id., In the Shadow of the Poorhouse (New York: Basic Books, 1986). 
My concern in this essay is not with the concept of social control itself but with the theoretical confusion the term signifies. I use the concept as an entry point to a wide range of substantive problems that are of concern to the sociolegal research community, including the operation of the criminal justice system, the growth of prisons, relations between the legal order and the helping professions, and the role of law in reproducing social inequality. My goal is not to present a new theory but to suggest in a preliminary way how issues of this sort might be addressed from the perspective of neoinstitutional theory, using Powell and DiMaggio's The New Institutionalism in Organizational Analysis as a point of departure. My first step, though, is to describe in a more systematic way the phenomena we might fruitfully try to explain from this perspective.

\section{PROBLEMATICS OF SOCIAL CONTROL}

A good analytical concept is denotative rather than connotative-it points in one direction to empirical indicators and in the other to abstract theory. My introductory comments suggest that the social control concept carries too many connotations, many of which contradict each other: it is a trope, not a concept. This is why, I suspect, Goffman wrote mainly of "stigma" rather than social control ${ }^{9}$ and why leading contemporary theorists like Garland ${ }^{10}$ are tending to use the concept of "punishment" to define the focus of their investigations. In this context I prefer the term sanctioning, since it includes a wider range of stigmatizing behaviors-not just criminal punishment but also the stigma of welfare dependency and mental illness. But where does such a concept fit in a larger program of research? Sanctioning is a useful concept in part because it suggests interesting variables. I would suggest three obvious ones that speak to a number of theoretical concerns. The first is simply the rate of sanctioning: What factors influence a society's capacity for applying stigma? The second variable concerns types of sanctions: What determines the relative emphasis on formal or informal, segregative or incorporative, punitive or therapeutic sanctions? Third, it is important to know who is punished: To what degree and how does ascribed status (especially race, gender, and class) figure in the sanctioning process?

To be helpful in this project, theory must address three issues that are conspicuously ignored or obscured by conventional theories that invoke the concept of social control: (1) Most fundamentally, why do deviants do what they do? This is the traditional, conventional problem of criminology. I will argue that institutional theory offers not just a new answer to an old ques-

9. Erving Goffman, Stigma: Notes on the Management of Spoiled Identity (Englewood Cliffs, N.J.: Prentice-Hall, 1963).

10. Garland, Punishment. 
tion but-by reframing the more general issue of social action-offers a new and more useful set of questions. (2) How do we account for variation in sanctioning regimes? This question requires that we account not only for specific strategies of punishment but also for the cognitive categories (formalized in varying degrees in law) that we use to distinguish deviance from normality, the profane from the sacred, and the impure from the pure. The larger theoretical problem here is the problem of agency, and institutional theory offers a model of historical change that transcends the limitations of both functionalism and moral entrepreneur models. (3) The obverse problem: How to make sense of the remarkable stability of sanctioning regimes? According to Simon, we are at the end of a long period of "penal modernism"-a 200-year run during which Western industrial societies based their responses to crime, mental illness, and poverty on a common discourse of scientific rationalism. ${ }^{11}$ The demise of this discourse might be greatly exaggerated; ${ }^{12}$ in any event it is interesting to wonder why it lasted as long as it did, considering the often high levels of public skepticism and low levels of empirical support for its efficacy.

\section{THE CONTRIBUTION OF NEOINSTITUTIONALISM}

\section{What's an Institution, and How Does the New Institutionalism Differ from the Old?}

The first question we must address is, What do we mean by the term institution? Ronald L. Jepperson's rather lengthy explication is useful here:

Institutions are those social patterns that, when chronically reproduced, owe their survival to relatively self-activating social processes. Their persistence is not dependent, notably, upon recurrent collective mobilization. ... That is, institutions are not reproduced by "action," in this strict sense of collective intervention in a social convention. Rather, routine reproductive procedures support and sustain the pattern, furthering its reproduction-unless collective action blocks, or environmental shock disrupts, the reproductive process. (At 145)

Jepperson's definition is intentionally broad, meant to include institutions at various levels of importance from the handshake to marriage to, presumably, sanctioning regimes. At all these levels, Jepperson focuses on the takenfor-grantedness of institutions: deliberate, planful social action is by definition not institutional, or even counter-institutional. This understanding dif-

11. Jonathan Simon, Poor Discipline: Parole and the Social Control of the Underclass, 1890-1990 (Chicago: University of Chicago Press, 1993).

12. David Garland, "Penal Modernism and Postmodernism" (unpub. MS., 1994). 
fers in important ways from the more common one as presented, for example, by Selznick..$^{13}$ Three points of comparison deserve mention here. ${ }^{14}$ The first concerns the relative emphasis on values and cognition. The Selznick model treats institutions as repositories of value, and individual commitment is therefore a byproduct of normative socialization (note here the continuity with Parsons). By contrast, neoinstitutionalists view institutions as cognitive phenomena-recipes and scripts for behavior that make the world manageable-and tend to assume that individual commitment is motivated by a fundamental need to reduce uncertainty. There is, however, some ambivalence on this point. Roger Friedland and Robert R. Alford argue, in direct critique of DiMaggio's earlier writing, ${ }^{15}$ for greater attention to the cultural aspects of institutions: Institutions classify phenomena, thus lending symbolic meaning (hence value) to experience. In this way Friedland and Alford attempt to reintroduce norms, but in a way that clearly differs from the views of Parsons and Selznick.

Second, neoinstitutionalists suggest a different way to understand the process of institutionalization, and this in turn implies a different relationship between the organization and its environment. In Selznick's terms, institutionalization occurs "when the tools of action become infused with value beyond the technical requirements of the task at hand"16 - it is, in other words, an internally generated process of culture creation. Organizations thus have a natural life-cycle: they begin as mere instruments but gradually grow into institutions as participants develop a sense of membership and shared commitment. The environment, conceived mainly as the organization's local community, is a set of forces to which the organization must adapt, and a potential source of co-optation and goal displacement. Neoinstitutionalists give primacy to the environment as the source of institutional models. ${ }^{17}$ The environment is conceptualized as a set of institutional "sectors" or "fields," each of which contains recipes for appropriate organizational forms and scripts for the appropriate performance of organizational roles. Institutional sectors transcend local communities and, in some cases, even national boundaries. Thus, to use a favorite example in the literature, elementary schools look much the same in Kansas and California; so, we might suggest, do prisons and mental health clinics. Early formulations of the neoinstitutionalist model tended to imply that institutionalization is an either/or phenomenon, but Jepperson (ch. 6) emphasizes that it is a relative (1948).

13. Philip Selznick, "Foundations of the Theory of Organizations," 13 Am. Soc. Rev. 25

14. For a thorough comparison of the old and new institutionalisms, see DiMaggio and Powell's Introduction at 11-15.

15. Paul J. DiMaggio, "Interest and Agency in Institutional Theory," in Lynne G. Zucker, ed., Institutional Patterns and Organizations (Cambridge, Mass.: Ballinger, 1988).

16. Philip Selznick, Leadership in Administration 17 (Evanston, Ill.: Row, Peterson, 1957).

17. See John W. Meyer \& Brian Rowan's ch. 2 and DiMaggio and Powell's ch. 3. 
accomplishment. Institutions rise, compete with each other, and decline in the context of larger historical changes. Thus institutions vary in their power to constrain the performance of organizations within a given sector.

Finally, it is important to mention an important continuity between the old and new institutionalisms. Both were developed as explicit critiques of utilitarian or economistic accounts of organizational behavior, and both suggest that explicit performance goals often fall victim to the organization's need for self-maintenance and continuity. In the old view, internal cultures generate pressures for goal displacement, and in the neoinstitutionalist model, efficiency is subordinated from the outset to conformity with institutional models. Powell (ch. 8) goes furthest in this regard, suggesting that even concepts like instrumental rationality, efficiency, and markets be viewed as institutional constructs. From either perspective, sanctioning agencies appear particularly vulnerable to institutionalizing pressures and hence to departures from instrumental rationality. This is so for three reasons. First, the goals of such agencies are ambiguous. Stated goals such as "justice," "rehabilitation," "crime prevention," and especially "social control" itself are simply too vague to suggest clear courses of action or sharp criteria of evaluation. The tendency, thus, is for agencies to develop more proximate standards by which to demonstrate their efficacy: crimes cleared by arrest, cases processed, and so on. Second, it follows that social control agencies operate with unclear and unproven technologies. Under such conditions of uncertainty about the relations between means and ends, it is likely that agencies will adopt organizational forms and standard operating procedures from legitimate models in the environment. Adoption of one model over another produces interesting variation: Police departments, which generally mimic the military, might emphasize gang sweeps or "community policing," and agents in different parole agencies might portray themselves under various circumstances as correctional officers or social caseworkers. Third, sanctioning agencies are loosely coupled. On the one hand, this means that the most crucial decisions are often made by personnel at the lowest level of the hierarchy. For police, the fateful decision to arrest is almost entirely up to the discretion of the patrol officer; in mental health clinics and social work agencies, intake workers (often professional apprentices) assign initial diagnoses. On the other hand, loose coupling implies that various agencies are not directly tied to each other, or to any overarching authority, by clear lines of authority. For example, police, courts, and correctional organizations are all separate agencies that make up a common throughput system. Each is beholden to a different level of government; their activities are coordinated, if at all, by what Meyer and Rowan (at 58-59) call a "logic of confidence and good faith"-ritual displays of mutual trust, that, with varying degrees of success, elide differences in interest and ideology. 


\section{The Problem of Institutional Stability}

Neoinstitutional theory is at its best in accounting for stability in policies and organizational forms. Foundational papers by Meyer and Rowan (ch. 2), DiMaggio and Powell (ch. 3), and W. Richard Scott and John Meyer (ch. 5) emphasize the inertial force exerted by institutional formations on organizations within their respective domains. Meyer and Rowan take issue with conventional theories that account for organizational structure in terms of the need to coordinate and control the kinds of complex relational networks that increasingly dominate modern societies. These conventional theories are derived in one way or another from Weber's model of bureaucracy: Bureaucratization, he wrote, was a necessary component of the expansion of markets and the consolidation of authority in the modern state. The Meyer-Rowan argument elaborates another aspect of Weberian theory-his model of political domination. ${ }^{18}$ Here the emphasis is on legitimation rather than efficiency: political authority, even in the modern form Weber termed "legal-rational," is not subject to validation based on externally derived criteria of efficiency but only in terms of a larger set of institutionalized rules. These rules are rational not in an instrumental sense but in the sense that they elaborate central cultural myths in a coherent way. New organizations and policies are constrained to replicate institutionalized forms or risk fatal delegitimation; thus one of the main effects of institutions is their own reproduction and elaboration. DiMaggio and Powell more directly acknowledge a debt to Weber, and push the argument a step further by suggesting three mechanisms of replication that seem most important in contemporary society: (1) the state acts coercively in some cases to force organizations to adopt certain forms or obey certain policies; (2) the professions are increasingly influential in suggesting normative standards for certain domains of activity over which they hold legitimate monopolies; (3) where uncertainty is high and neither state nor professional mandates are definitive, organizational actors often simply imitate strategies of others that appear successful. To DiMaggio and Powell, these mechanisms suggest why, in modern societies, institutional fields are characterized by increasing homogeneity of organizational forms.

From Weber's day to the present, law appears in the literature as a dominant institutional field and as an exemplar of inertial, self-referential development. This is most obviously so in democratic states, where caselaw is justified by reference to a vanishingly long chain of precedent, positive law is enacted by legislatures according to constitutionally validated rules, and constitutions themselves are legitimated in terms of abstract principles such as justice, citizenship, and the rule of law rather than kinship, tradition, or raw power. In other words, modern law is premised on the norm of

18. Hamilton \& Sutton, 18 Theory $\mathcal{E}^{\prime}$ Soc $^{\prime} y$ (cited in note 2). 
autonomy from extralegal pressures. ${ }^{19}$ Thus the central goal of legal social control-as exemplified by criminal law-is not given by any substantive policy mandate but by the procedural requirements of the rule of law. In practice, of course, criminal law is oriented toward a number of general substantive goals such as the maintenance of order and the protection of property, and toward more specific goals such as punishment, rehabilitation, and deterrence. These latter goals are somewhat mutually exclusive and are salient in varying degrees at different times. In addition, there are mechanisms of control outside the legal system proper, such as the mental health and welfare systems, where the rule of law is deliberately subordinated to policy goals. The question remains: How is institutional stability possible in the absence of any demonstrable effectiveness?

The answer to this question is, simply, professionalization, or more specifically the medicalization of punishment. In the United States in particular, substantive decisions concerning the application of sanctions are relegated to putative experts: probation and parole officers, psychiatrists, social workers, and the like. ${ }^{20}$ From a neoinstitutionalist perspective, professionalization stabilizes sanctioning regimes in two ways. First, claims to professional expertise buffer sanctioning agencies from lay criticism by shifting the criteria of accountability from outcomes to process. Second, professional displays of mutual deference and good faith help to lubricate interactions between agencies. Such displays give a sense of coherence to the disparate actions of loosely coupled agencies and render the system as a whole more adaptive to environmental changes. Third, and perhaps most important, the helping professions are based on a pathogenic model of deviance that dramatizes dominant cultural norms about the individual nature of the self. As writers from Pound to Garland have emphasized, ${ }^{21}$ the individualized treatment orientation of the helping professions is quite different from the assumption of individual responsibility that is central to the rule of law: While the latter attempts to fit the punishment to the crime, the former attempts to fit the punishment to the criminal. I will have more to say below about the ideological conflict between legalistic and therapeutic models of control. My point here is to emphasize that the incorporation of nonlegal professionals at the boundaries of the legal system has become an important source of legitimacy.

19. Philippe Nonet \& Philip Selznick, Law and Society in Transition: Toward Responsive Law (New York: Harper \& Row, 1978).

20. See Hamilton \& Sutton, 18 Theory \& Soc'y at 26-31.

21. Roscoe Pound, "The Limits of Effective Legal Action," 27 Int'l J. Ethics 150 (1917); David Garland, Punishment and Welfare: A History of Penal Strategies (Brookfield, Vt.: Gower, 1985). 


\section{The Problem of Institutional Change}

While the core technologies of sanctioning regimes tend to remain stable over time, they are prone to periodic spasms of reform at their peripheries. Indeed, Foucault has argued that the characteristic feature of the modern prison is its ability to "re-form" itself from time to time-to generate anomalies and, simultaneously, resolutions to those anomalies. ${ }^{22}$ Much of the early empirical research in support of neoinstitutional theory was concerned with the diffusion of new organizational practices such as civil service reform ${ }^{23}$ and public education. ${ }^{24}$ Modernization theory suggests that the diffusion of administrative innovations should be driven by functional requisites-that is, social units are likely to adopt new practices insofar as they have the need for change, the resources required to create new structures, and adequate information about alternative forms of organizing. ${ }^{25}$ Neoinstitutional theory suggests to the contrary that diffusion is an ideological process and that adoption is likely to occur independently of functional imperatives. Many early studies showed a strikingly consistent pattern: While early innovators are often the most "modernized"-the most developed societies or nation-states, the largest cities or most complex organizations-subsequent adoption is more nearly random, suggesting an ideologically driven bandwagon effect. Processes of this sort also operate in sanctioning regimes. My research on the history of American juvenile justice shows that the adoption of juvenile reformatories, juvenile courts, and decarceration legislation had little to do with real problems of delinquency but much to do with ideological conformity. ${ }^{26}$

In diffusion studies of this sort, the focus of analysis is on the adopting unit-the nation-state, the city, or the organization. Moreover, as a practical analytic necessity they typically assume that only one institution is at stake in a given situation: States either adopt public schooling or they do not; cities either enact civil service requirements or they do not. But modern societies are complex institutional environments. Recognizing this fact, many of the papers in the Powell and DiMaggio volume attempt to shift the level of analysis upward, to discuss the origins of new institutional forms as well as change within and conflict between institutional fields. These ideas

22. Michel Foucault, Discipline and Punish: The Birth of the Prison (New York: Pantheon, 1979).

23. Pamela S. Tolbert \& Lynne G. Zucker, "Institutional Sources of Change in the Formal Structure of Organizations: The Diffusion of Civil Service Reform, 1880-1935," 28 Admin. Sci. Q. 22 (1983).

24. John W. Meyer, David Tyack, Joane Nagel, \& Audri Gordon, "Public Education as Nation-Building in America: Enrollments and Bureaucratization, 1870-1930," $85 \mathrm{Am}$. J. Soc. 591 (1979).

25. See, e.g., Arthur L. Stinchcombe, "Social Structure and Organizations," in James G. March, ed., Handbook of Organizations (Chicago: Rand-McNally, 1965).

26. John R. Sutton, Stubborn Children: Controlling Delinquency in the United States, 1640-1982 (Berkeley: University of California Press, 1988) ("Sutton, Stubborn Children"). 
are developed in two general ways. First, some writers argue that apparently stable institutional orders can be distupted, and institutional change initiated, as a result of exogenous shocks from the environment. This is a key theme in both Neil Fligstein's (ch. 13) study of diversification among Fortune 100 firms and Steven Brint and Jerome Karabel's (ch. 14) account of the transformation of American community colleges. This approach seems, if only implicitly, to divide the social world into $(a)$ institutions and $(b)$ everything else, the latter presumably including the economy, technology, war, demographic shifts, and so on; the imagery of "shock" suggests that institutions are naturally stable until something happens "out there." A second and more ambitious approach is to suggest, in Friedland and Alford's (ch. 10) terms, that the social world is densely populated by "multiple institutional logics" that coexist in varying degrees of conflict and accommodation. They argue that these logics can only be understood by a social theory that operates at three levels of analysis: "individuals competing and negotiating, organizations in conflict and coordination, and institutions in contradiction and interdependency" (at 240-41). Similarly, Jepperson (ch. 6) encourages us to think of the institutional environment as a fuzzy and chronically contested terrain in which institutional effects operate at multiple levels of organizations, regimes, and cultures. Both these chapters suggest a tectonic metaphor: Institutions are not fixed but rather plastic entities in a constant process of growth and erosion; innovations and transformations are most likely to occur at points of friction, collision, and subduction. ${ }^{27}$ Stability is precarious: It is maintained only to the degree that the various levels of culture, institutional regime, organizational structure, and practical action are isomorphic, thus allowing individuals to orient their actions to meaningful symbolic categories. Contradictions emerging at any level have implications for the integrity of every other level.

Both accounts of change-what we might term the "shock" model and the "institutional contradictions" model-are applicable to the study of change in sanctioning regimes. For example, many revisionist accounts of sanctioning policies in the United States suggest that major reforms have occurred as responses to wider crises of legitimation. Thus, for example, the wholesale founding of penitentiaries, mental hospitals, and juvenile reformatories in the 1810 s and 1820 s dramatized widespread concern among various publics about the decline of the Federalist party, the leveling effects of Jacksonian democracy, and the vast increase in immigration that followed the War of $1812 ;^{28}$ further reform waves coincided with the crises of Progressivism and the civil rights movement. These shocks generate challenges to the taken-for-granted policies by which sanctioning agencies

27. John Mohr deserves credit for the tectonics imagery.

28. See, e.g., David J. Rothman, The Discovery of the Asylum (Boston: Little, Brown, 1971); Sutton, Stubbom Children chs. 2-3. 
channel individuals into deviant roles. For example, waves of immigration raise fundamental questions about the moral boundaries of American society and about the efficacy of existing socializing institutions. Reform, then, is a symbolic struggle to reassert the traditional moral order in the face of external challenges.

But it is also possible to suggest, following Friedland and Alford, that reform is a response to institutional contradictions. As I have already suggested, control regimes in Western democracies are unstable alloys of varying institutional logics, each of which embodies a different image of the moral order and carries different implications for the organization of sanctioning agencies and deviant identities. At the most general level, contradictions between the logic of punitive justice and the logic of treatment are the source of innovation and transformation. ${ }^{29}$ For example, humanitarian reformers and treatment professionals have repeatedly criticized the adversarial legal system for its harsh and stigmatizing response to various deviant groups, especially children, casual criminals, substance abusers, and the insane. Their reform proposals typically call for specialized treatment agencies that operate with greater discretion than is normally available under formallegal auspices-hence mental hospitals until the 1960s, juvenile courts, and adult probation and parole. On the other hand, law-and-order conservatives and civil libertarians alike have repeatedly criticized the broad discretion that is central to the treatment model. This unstable alliance has had marked effects in the United States over the past few decades: court rulings and legislation have reasserted some due process rights that are owed to children, paroled convicts, welfare recipients, and the insane; at the same time an overall increase in punitiveness has led to a threefold increase in prison populations.

This account of the internal contradictions of the social control system is not new, but a neoinstitutional perspective on this issue raises two points that are not ordinarily noted in the literature. First, the dialectic between punishment and treatment is not just a conflict of ideas or disembodied ideologies. Values are surely at stake, but so are political power, organizational resources, and the everyday cognitive expectations of actors in the sanctioning drama. Neoinstitutional theory encourages us to think about the ways institutional logics both constrain and enable new forms of social action. An example of this that comes readily to mind is President Clinton's "centrist" approach to welfare, drugs, and crime. His policies do not simply

29. It is possible to break this general distinction down further and to discuss more finegrained differences among institutional logics. For example, the punitive justice model can be motivated either by the logic of just deserts (it is morally right to punish offenders, regardless of any instrumental outcome) or the logic of deterrence (punishment discourages further deviance). Variations on the treatment model include eugenics, various psychologically oriented approaches, and welfarist approaches that emphasize the pathogenic aspects of communities and subcultures. 
stake out a median position between the extremes of punitiveness and therapy. Rather, they combine elements of different institutional logics-for example, time limits on welfare benefits (a punitive move) and job training (a therapeutic move)-into a qualitatively new package. The trick, from his point of view, is to discursively co-opt members of liberal and conservative camps; the danger, again from his perspective, is that his policies will displease everyone. A neoinstitutional perspective can help us analyze the fate of these policies.

Second, it is important to recognize that institutional contradictions are worked out in different ways in different societies. This insight suggests valuable opportunities for comparative analysis. While I have drawn examples from the American experience, it appears that the United States is unique among industrial democracies both for its level of punitiveness and for the degree to which problems of crime and poverty are politicized. Why should this be so? Three factors seem important, each operating at a different level of American society. The first is the stubborn persistence of the cultural myth that crime, poverty, and other forms of deviance are the results of individual moral faults rather than structural inequities. I have argued elsewhere that this myth was originally a byproduct of Calvinism, ${ }^{30}$ but since the late 19th century it has been expressed in more secular and scientific terms by the helping professions. The second factor is the institutional structure of the American state. The combination of divided sovereignty (federalism) and weak bureaucratization creates uncertainty about the boundary between public and private spheres, about which levels and agencies of government are responsible for what kinds of social problems, and about which institutional logics should govern different policy arenas. Such uncertainty invites competition over resources that is played out in the political arena in symbolic terms; in the United States, then, social control policies are likely to be particularly vulnerable to shifts in the political winds. The third factor is the organizational structure of sanctioning agencies. I have already emphasized the loosely coupled nature of authority relations in the social control system. This loose coupling is on the one hand an adaptive response to uncertainty over goals and technologies: To maintain access to resources and clients, agencies with different agendas must find ways to cooperate with each other and must be able to account for their actions to multiple constituencies in terms of multiple institutional logics. But on the other hand it must be noted that loose coupling helps to reproduce uncertainty and contradiction. As neoinstitutionalists have long argued (e.g., Meyer and Rowan, ch. 2), organizations with fuzzy or conflicting mandates will attempt to control the standards by which their activities are evaluated, and in particular will seek to emphasize process criteriacredentials, structures, and procedures-rather than outcomes. One result is

30. Sutton, Stubborn Children. 
that institutional contradictions typically remain latent, or at least unacknowledged, and the possibility of a fundamental reorientation of policy is rendered literally unspeakable.

\section{The Problem of Social Action}

Neoinstitutional theory also carries implications for the way we think about deviance and control at the level of face-to-face interaction. From this perspective, the work of sanctioning agents is to sort potential deviants into meaningful taxonomic categories, assign the relevant attributions, and apply the prescribed sanctions. The most authoritative taxonomies are those that appear in official texts such as the criminal code, used by criminal justice agents to categorize offenders, and the Diagnostic and Statistical Manual used by mental health professionals to categorize patients. Official ideology and functionalist theory alike suggest that the attribution process is a straightforward matter of using legal, professional, or bureaucratic rules to match behavior to categories. But our assessment so far suggests that the process is much more complicated and less rational than that. Where goals are ambiguous, shifting, or conflicting, as tends to be the case in sanctioning agencies, the expectation of rationality places a tremendous cognitive burden on individuals. But individual rationality is bounded, and it is unreasonable to expect the aggregate of individual judgments to outweigh the stupidity of the organization as a whole. Moreover, as jurists as early as Holmes and Pound recognized, ${ }^{31}$ legal behavior that deviates from prescribed rules is not random or entropic, and does not merely "fall short" of professed goals; rather it is typically patterned and oriented toward latent goals. How do we account for patterned action of this sort?

Ethnomethodologists and phenomenologists have been aware of this problem for some time, and DiMaggio and Powell are shrewd to draw them into their essay (at 19-22). This view suggests that individuals orient their actions toward local, practical rationality rather than deeply internalized values. Indeed, ethnomethodological research has shown in a number of settings that the process of attributing identities to deviants is neither mechanical nor natural but rather is an interpretive, sense-making activity. Official taxonomies of deviance, whether in legal codes or psychiatric nosologies, are discursive resources that agents use strategically to transform ambiguous trouble situations into successfully closed cases. Thus the application of deviant labels is heavily influenced both by organizational priorities and by the ascriptive status of clients. The classic study in this regard is

31. Oliver Wendell Holmes, Jr., The Common Law (Boston: Little, Brown, 1905); Pound, 27 Int'l J. Ethics (cited in note 21). 
Sudnow's research on plea bargaining. ${ }^{32}$ Sudnow found that public defenders and prosecutors orient their negotiations not to how the offender's behavior fits the legal offense with which he is charged but to how the offender's external characteristics fit commonly held stereotypes of "typical" offenders. Where the fit is close-a "normal crime"-a plea bargain can be efficiently struck for the "going rate." Institutional routines are disturbed when the fit is poor: when, for example, high-status clients are accused of typically low-status crimes or when accused offenders stubbornly insist on their innocence.

Studies in a variety of settings show that stereotypes of "normal deviants" help social control agents stabilize their interactions and permit meaningful categorizations under conditions of ambiguity. From a neoinstitutional perspective, the attribution process is a form of cultural accounting. From here it is a short step to think about how institutional processes influence the social organization of deviant careers. This would require a reconsideration of two hallowed concepts in the deviance literature: neutralization and deviant subcultures. Neutralization refers to discursive strategies used by deviants to rationalize their behavior in terms of conventional norms. ${ }^{33}$ Most studies of neutralization offer only descriptive lists of such accounts-for example, a deviant might claim that a victim invited the deviant act, that he or she was under the influence of alcohol or drugs, or that "everyone does it," therefore it isn't really wrong. Little attention has been paid to the origins of these accounts, how they vary across settings, or how effective they are in stabilizing deviant careers. The issue of subcultures arises here, since a large body of literature argues that gangs, neighborhood cultures, and other stable deviant associations provide collective accounts that can be deployed by individual members to ward off disreputable associations. For example, Riess found that young male hustlers manipulated their encounters with homosexual clients so that they could avoid being seen as homosexual themselves. ${ }^{34}$ Much of the subcultures research has been closely linked to conventional functionalism, treating gangs and troublesome communities as sites of defective socialization. A newer tradition, associated with the "Birmingham school" of cultural studies, ${ }^{35}$ romanticizes working-class youth subcultures as "sites of resistance" to dominant capitalist institutions. This approach is no less functionalist than the old, because the meanings associated with styles of dress and behavior are

32. David Sudnow, "Normal Crimes: Sociological Features of the Penal Code in a Public Defender Office," 12 Soc. Prob. 255 (1965).

33. Gresham Sykes \& David Matza, "Techniques of Neutralization: A Theory of Delinquency," 22 Am. Soc. Rev. 664 (1957). (1961).

34. Albert J. Reiss, Jr., "The Social Integration of Queers and Peers," 9 Soc. Prob. 102

35. Stuart Hall, The Hard Road to Renewal: Thatcherism and the Crisis of the Left (London: Verso, 1988). 
primarily those of the investigators rather than the participants. In short, by treating neutralization work as something only deviants do, and by treating deviant subcultures as inherently pathological (or revolutionary), the deviance literature has missed a valuable opportunity for synthesis. A neoinstitutional theory would begin with the assumption that all competent members of society engage in a constant process of cultural accounting in order to ascribe meaning to their past actions and to chose among future courses of action. They do so not in a vacuum, however, but by drawing on a collectively validated repertoire of symbols-what Swidler calls a "tool kit" of representations ${ }^{36}$-from which to construct a reputable self-image. These symbols are a form of cultural capital, and like any resource they are unevenly distributed across society. ${ }^{37}$ Some people have broader repertoires than others, and one's choice of neutralization strategies is likely to depend systematically on access to symbolic resources-in short, placement in the institutional structure of society.

\section{DISCUSSION}

In this essay I have argued that neoinstitutional theory provides a valuable resource for rethinking what has traditionally been referred to as "social control." Social control is originally an American concept, consciously developed to account for social order without invoking European notions of hierarchy and political sovereignty. As such it has two meanings, both of which require revision. First, it projects an assumption that individuals act on the basis of deeply internalized norms-that they are, in Garfinkel's term, "cultural dopes." ${ }^{38}$ Second, it implies that these norms represent some broader and typically unobserved set of interests-of society as a whole (in Parsons's version) or of a conspiratorial ruling class (in the neomarxist version).

Thus the first, minimal step in the revisionist project must be to redefine the object of our investigations. I suggested sanctioning as a notion that is empirically fairly precise and nonetheless applicable to a broad range of settings. The more important part of the argument was to sketch out the potential contribution of neoinstitutionalism to a nonfunctionalist theory of sanctioning. From this perspective, sanctioning is a process of cultural accounting that involves sorting people into symbolic categories. As Mary Douglas has argued, institutions naturalize classification systems, lend them

36. Ann Swidler, "Culture in Action: Symbols and Strategies," 51 Am. Soc. Rev. 273 (1986).

37. Philippe Bourdieu, Outline of a Theory of Practice (New York: Cambridge University Press, 1977); id., Distinction: A Social Critique of the Judgement of Taste (Cambridge: Harvard University Press, 1984). 1967).

38. Harold Garfinkel, Studies in Ethnomethodology (Englewood Cliffs, N.J.: Prentice-Hall, 
intellectual coherence, and give them moral resonance. ${ }^{39}$ Thus, I suggested, to account for the general stability of sanctioning regimes in Western democracies, we need to understand the internal structure of those regimes as well as the forces that impel sanctioning agencies toward isomorphism with their institutional environment. To account for changes in sanctioning regimes, I drew on the concepts of institutional logics and institutional contradiction to argue that reform is in many respects a discursive struggle. To understand why one model of sanctioning achieves ascendancy over another, we must in particular examine the alignment of the state, sanctioning agencies, and professional groups in the politics of representation. Finally, I suggested that neoinstitutional theory can contribute to our understanding of the sanctioning process at the microsocial level as well. This approach reverses conventional social psychology: Individuals do not act on the basis of internalized motives; rather they discover their motives through action. This has implications for two well-established areas of research. One concerns the actions of sanctioning agents: They use official taxonomies to solve problems of practical action as they are given in particular organizational settings; their attributions are likely to be powerful insofar as they resonate with wider institutional logics. The second area concerns the behavior of deviants themselves. Here the initial hypothesis would be that deviants and normals differ not primarily in terms of internalized motives but in their access to legitimate action scripts and naturalizing accounts. Of these two areas, the second is surely the more challenging and less developed.

39. Mary Douglas, How Institutions Think ch. 9 (Syracuse, N.Y.: Syracuse University Press, 1986). 


\section{Fields of Practice: \\ Connections between Law and Organizations}

Walter W. Powell

It is, of course, both a privilege and a challenge to have one's work attended to in the thorough and thoughtful manner exemplified by Professors Suchman and Edelman's and Professor Sutton's essays. ${ }^{1}$ The New Institutionalism in Organizational Analysis ${ }^{2}$ has been subject of many review symposia-in journals of accounting, business, political science, and sociology. But the traffic has never been two-way: our work is typically imported into new domains, but here we also have the opportunity to see how law and society research might enhance institutional analysis. In reading and reflecting on these valuable commentaries, I am pulled by divergent reactions: "Why didn't we think of that?" and "that's not what we meant" are the most common. But rather than play out these responses in print, I plead nolo contendere and concur with Suchman and Edelman's contention that institutional analysis has treated the law and the legal environment in an overly determinist fashion. In focusing on the letter of the law and its purported impact, institutional analysis neglects the extent to which the law and the legal environment are subject to negotiation, interpretation, and contestation.

The view of the law as a coercive constraint stems in part from the lack of a satisfactory theory of the state in organization theory. Is government a

Walter W. Powell is a professor of sociology at the University of Arizona. He is grateful to Cal Morrill for helpful comments on an earlier draft.

1. Mark C. Suchman \& Lauren B. Edelman, "Legal Rational Myths: The New Institutionalism and the Law and Society Tradition," 21 Law \& Soc. Inquiry 943 (1996); John R. Sutton, "Rethinking Social Control," 21 Law \& Soc. Inquiry 959 (1996).

2. Walter W. Powell \& Paul J. DiMaggio, eds., The New Institutionalism in Organizational Analysis (Chicago: University of Chicago Press, 1991) ("Powell \& DiMaggio, New Institutionalism"). 
supra-organization to which all other entities must inevitably conform? Clearly not, but neither is government and its regulatory arm an arena in which everything is constantly up for grabs. The conception of the law as a binding force in institutional analysis rests on the simplifying assumption that the judiciary and legislative branches play critical roles in formulating and maintaining the rules of the game for corporate actors. Suchman and Edelman remind us that the law and society tradition provides abundant evidence that these rules are neither etched in stone nor constant across fields. The question, then, is just how malleable is the law?

In an excellent survey, Scott offers the following definition:

Institutions consist of cognitive, normative, and regulative structures and activities that provide stability and meaning to social behavior. Institutions are transported by various carriers - cultures, structures, and routines-and they operate at multiple levels of jurisdiction. ${ }^{3}$

Scott points out that institutional analyses rest on "three pillars"-regulative, normative, and cognitive. While all three are relevant for the law, most researchers have treated the law as a rule-making, sanction-applying process that regulates behavior. Consequently, the law appears as a constraining force; in contrast, the normative and cognitive pillars leave much more room for negotiation and muddling through. Normative systems define obligatory behavior, but codes of conduct are rarely spelled out completely in advance. Individuals and organizations "edit" their behaviors in the course of interacting with others. The cognitive component stresses the sense-making function: individuals and organizations navigate through social routines in accordance with deep-seated expectations as to "the way things are done around here." Thus while institutionalists stress that a good deal of social life is subject to interpretation, and that "rule-following" involves the act of matching appropriate behavior with specific circumstances, the regulative pillar has been viewed as more foundational. Hence it is accorded more status as a building block, as a provider of key precedents, with greater capacity to punish. I take the main thrust of Suchman and Edelman's and Sutton's essays to be that while rule systems have the capacity to control, the functioning of the law depends to a considerable degree on its execution: How are rules defined in practice? Who, if anyone, monitors compliance and ascertains whether behaviors match intentions? Which agents have the relevant jurisdiction?

In my response, I want to accomplish two things. One, I survey possible linkages between organizational and legal scholarship, with an eye to promoting greater cross-fertilization. Then I take up the challenge posed by the

3. W. Richard Scott, Institutions and Organizations 33 (Thousand Oaks, Cal.: Sage Publications, 1995). 
previous essays and reflect on the implications of a "law as process" view for institutional analysis.

\section{Law and Organization Theory}

Curiously, there has been limited contact between the study of organizations and the law. Researchers in organization studies have evinced scant awareness of legal scholarship, and law school faculty have pursued their work with little recognition of organizational research. This state of affairs is odd, given the obvious points of commonality in the subjects being studied. The nature of corporate control, the role of boards of directors, forms of governance, the role of venture capital, business political activity, and racial and gender discrimination are but a small sample of topics studied in detail by both legal and organizational scholars. Moreover, intellectual ancestry also suggests there should be greater contact. Consider the writings of Max Weber or John Commons-both argued forcefully that the study of governance demanded attention to both law and organizations. In recent years, this divide has been bridged, first by law and economics researchers, whose work is frequently rooted in a transaction costs framework, and more recently by scholars who approach the analysis of the law from an institutional perspective.

Viewed broadly, three areas stand out as profitable avenues for linking the law and organization theory. (1) Law is practiced in an organizational setting that shapes its conduct. (2) The law is carried out in an arena that is populated by multiple organizational jurisdictions, with competing claims of professional expertise. (3) The law serves as both a normative and a regulatory environment in which organizations operate. I address, albeit briefly, each of these areas in turn.

Law firms are complex organizations in their own right, with sophisticated career ladders and incentive systems. Changes in economic activity also shape the structure of legal firms-witness the spread of branch and multinational offices, the growth of specialized firms in high technology and intellectual property, and the changes made in partnership structures to accommodate labor market developments. There is an expanding line of research on the organization of legal practice 4 but very little effort to analyze and compare different professional services, that is, medicine, architecture, accounting, or consulting. Nor do these analyses of law firms draw on

4. Robert Nelson, Partmers with Power: the Social Transformation of the Large Law Firm (Berkeley: University of California Press, 1988); Walter W. Powell, "Institutional Effects on Organizational Structure and Performance," in L. G. Zucker, ed., Institutional Patterns and Organizations (Cambridge, Mass.: Ballinger, 1988) ("Powell, 'Institutional Effects"); Marc Galanter \& Thomas Palay, Tournament of Laurjers: The Transformation of the Big Law Firm (Chicago: University of Chicago Press, 1991). 
organizational theory in any systematic way. In contrast, there is a rich and growing literature on the accounting profession, as both a professional services organization and as a rule-making practice, that employs organizational theory extensively. ${ }^{5}$ Accounting is now conceptualized through an organizational lens as a social and institutional practice. Far from merely reporting the cold facts of economic activity, accounting shapes how information is created, processed, and presented for both internal and external consumption. Accounting researchers are demonstrating how the construction of "accounts" shapes lines of authority and the focus of activity inside organizations, while simultaneously creating an evaluative framework with which other organizations, analysts and investors, and regulators assess performance. Seen from the vantage point of recent studies of accounting, research on the organization of law is too insular, missing an opportunity to assess how the broader social environment modifies conduct inside the law firm as well as to analyze how the organization of law firms influences how clients interact with the law.

In his essay, Sutton suggests that social control in democratic polities occurs in a competitive context-different administrators, agencies, offcials, and professionals embody divergent missions and interpretations of the law. At the most general level, there is a contest between the logic of punitive justice and the logic of treatment. Organizational researchers have argued that even though organizations are shaped by institutional systems, the degree of coherence or centralization in the larger environment may vary considerably. 6 Conflicts over jurisdiction and overlapping levels of authority are thus reflected in the structure and policies of organizations. There is, then, a rich empirical literature in organization theory that bears directly on the question of how contradictions in the conduct of the law are resolved.

Consider the simple distinction between a coherent and a fragmented institutional environment. The former consists of relatively few constraints and opportunities, and these levers of control are generally linked to one

5. Bruce Carruthers, "Accounting, Ambiguity, and the New Institutionalism," 20 Accounting, Organizations, \& Soc'y 313 (1995); Mark A. Covaleski \& M. W. Dirsmith, "An Institutional Perspective on the Rise, Social Transformation, and Fall of a University Budget Category," 33 Admin. Sci. Q. $562-587$ (1988); Anthony G. Hopwood \& Peter Miller, eds., Accounting as Social and Institutional Practice (New York: Cambridge University Press 1994); Royston Greenwood \& Bob Hinings, "An Institutional Theory of Change: Contextual and Interpretive Dynamics in the Accounting Industry," in W. W. Powell \& D. Jones, eds., Bending the Iron Cage: Institutional Dynamics and Processes (forthcoming); Stephen Mezias, "An Institutional Model of Organizational Practice: Financial Reporting at the Fortune 200," 35 Admin. Sci. Q. 431 (1990).

6. John W. Meyer, W. R. Scott, \& D. Strang, "Centralization, Fragmentation, and School District Complexity," 32 Admin. Sci. Q. 186 (1987); Powell, "Institutional Effects"; Thomas D'Aunno, R. I. Sutton, \& R. H. Price, “Isomorphism and External Support in Conflicting Institutional Environments: A Study of Drug Abuse Treatment Units," 14 Acad. Mgmt. J. 636 (1991); W. Richard Scott \& J. W. Meyer, "The Organization of Societal Sectors: Propositions and Early Evidence," in Powell \& DiMaggio, New Institutionalism. 
another and exhibit common concerns. A fragmented environment is one with conflicting and disconnected constraints and opportunities. Official mandates are at cross purposes; the organization confronts a field that speaks with many voices, making multiple, inconsistent demands. In research on a wide range of organizations, evidence has accumulated that fragmentation at the institutional level generates both greater administrative complexity within organizations and heightened internal politics. In short, the administrative structure of the organization reflects the complex array of external constraints and opportunities that it confronts. Nor is this situation altogether unhealthy; not only do organizations facing complex environments have more "wiggle room" and greater opportunity, the clash of views both internally and externally motivates the hard but necessary work of building consensus, which can often serve as a spur to innovation.

Moreover, the law provides "paradigms for arguments,"7 which can frame how negotiations and litigation are carried out. Using a legitimated account enhances the credibility and comprehension of an argument. But such signals of reasonableness are less efficacious in settings where multiple jurisdictions clash and divergent forms of argument are regarded as legitimate. Again, disputes among competing paradigms of argument can produce opportunities for social and legal change.

The discussion of the degree of fragmentation or centralization of authority in the external environment leads directly to a third area of research that bears heavily on the law. Organizations researchers have long argued that law helps create and sustain a normative environment that exerts influence on the behavior of organizations. Rather than posing the question that Tyler does, Why do people obey the law? ${ }^{8}$ they ask how and when organizational policies reflect cultural support and consonance with the law. Interestingly, legal scholars such as Tyler and institutionalists reach similar conclusions as to the nature of legitimacy. Rather than reflecting self-interested or overtly strategic calculations, legitimacy depends heavily upon normative conceptions about what is proper and obligatory. Tyler's research suggests that people evaluate the legitimacy of their experience with the law by considering processual factors, such as whether they had an opportunity to state their case or were treated with dignity and respect. His research is consonant with the broad view of legitimacy taken by Berger and Luckman: "legitimacy justifies the institutional order by giving normative dignity to its practical imperatives."

7. John L. Comaroff \& Simon Roberts, Rules and Processes: The Cultural Logic of Dispute in an African Context (Chicago: University of Chicago Press, 1981). 1990).

8. Tom R. Tyler, Why People Obey the Law (New Haven, Conn.: Yale University Press,

9. Peter Berger \& Thomas Luckman, The Social Construction of Reality 93 (Garden City, N.Y.: Doubleday, 1967). 
But governments cannot confer legitimacy on their policies just by legislation, and both the law and organizations literature are replete with studies of firms that resist or evade government dictates, agencies-even legal ones-rife with corruption and illegality, and corporate actors who try to strategically cultivate the patina of legitimacy while pursuing self-interested policies. How, then, does the law exert influence on the public behavior of organizations? Perhaps the most sophisticated answer to this question comes from the work of Edelman and her colleagues..$^{10}$ They argue that the law has a differential impact on public life by creating standards of faimess, which some organizations are more likely than others to adopt. In research on rules of due process for nonunion employees and on equal employment opportunity, Edelman found that larger organizations, firms with a closer proximity to the public sector, as well as those with highly developed personnel offices were most likely to develop procedures that are responsive to the legal environment. This rich vein of work is notable on several counts:

1. It demonstrates that organizations vary widely in their sensitivity to the law and conceptions of legitimacy

2. It raises critical questions about the strategic nature of legitimacyafter all, larger firms with government contracts are more "at risk"

3. It shows the important mediating role of in-house staff in interpreting and implementing the law and suggests that their efforts often greatly exceed the possible threat of sanction

I have sketched three areas where legal and organizational scholarship can be joined, and where the potential for rich cross-fertilization is high. In each case, I have been something of an "organizational imperialist," suggesting that insights from organization theory, and an institutionally oriented perspective at that, provide great purchase. Let me now try to turn the tables and illustrate how ideas that have been developed by law and society scholars might inform organizational research.

\section{Insights from Law and Society}

The core arguments of the law and society tradition concern the relative inefficacy of formal law and the significant impact of procedural jus-

10. Lauren B. Edelman, "Legal Environments and Organizational Governance: The Expansion of Due Process in the American Workplace," 95 Am. J. Soc. 1401 (1990); id., "Legal Ambiguity and Symbolic Structures: Organizational Mediation of Civil Rights Law," 97 Am. J. Soc. 1531 (1992); also see Lauren B. Edelman, Steven E. Abraham, \& Howard S. Erlanger. 1992. "Professional Construction of Law: The Inflated Threat of Wrongful Discharge," 26 Law \& Soc'y Rev. 47 (1992); Lauren B. Edelman, Howard S. Erlanger, \& John Lande, "Internal Dispute Resolution: The Transformation of Civil Rights in the Workplace," 27 Law $\&$ Soc'y Rev. 497 (1993). 
tice, or law-in-action. There is a considerable body of evidence as to the lack of potency of law-on-the-books, ranging from studies of the ineffectiveness of the Supreme Court as an agent of social change ${ }^{11}$ to Macaulay's classic studies of pre-contractual solidarity ${ }^{12}$ to research on the limited contribution exerted by law in the maintenance of social order in tightly knit communities. ${ }^{13}$

At first approximation, this research is a serious challenge to institutional theories of organization, a point developed well by Suchman and Edelman. But recognize the task that institutional analysis faces. The resource environments of organizations vary greatly, there are critical differences in the structure of industries, government and the political process generate multiple levels of overlapping regulation, and organizations differ in their capability to shape the expectations of their external environments. ${ }^{14}$ In the midst of all these factors producing heterogeneity, researchers treated the law-on-the-books as authoritative and coercive simply to tidy up some of the messiness of organizational life. So the message that the influence of law-on-the-books is limited only adds more complexity and indeterminacy. Or does it?

A different way of reading the law and society literature on law-inaction is that fields vary in their forms of governance, but running throughout very different settings is a concern for establishing a firm social order, be it private or public. That all areas of organized life should prefer accepted rules of the game to disorder is obvious once stated, but by thinking only of the law-on-the-books, organizational scholars have missed out on the opportunity to theorize why forms of governance vary and have failed to see that law and the legal profession play a critical role in both public and private orders.

Organizational scholars are well aware that fields vary widely in their modus operandi, from sectors controlled largely by market forces to those with well-established industry norms and practices to sectors with highly centralized government regulation. But we have long puzzled that different modes of control do not map neatly onto industry structure. Some fields exhibit little organization, low levels of interaction, and limited awareness of boundaries while others are tied together by densely knit networks of association. These differences in embeddedness show little association with formal legal controls. But the failure to find a connection between industry

11. Gerald Rosenberg, The Hollow Hope: Can Courts Bring About Social Change? (Chicago: University of Chicago Press, 1991).

12. Stewart Macaulay, "Non-contractual Relations in Business," 28 Am. Soc. Rev. 55 (1963); id., Law and the Balance of Power: The Automobile Manufacturers and Their Dealers (New York: Russell Sage Foundation, 1966).

13. Robert Ellickson, Order without Law (Cambridge: Harvard University Press, 1991).

14. Walter W. Powell, "Expanding the Scope of Institutional Arguments," in Powell \& Dimaggio, New Institutionalism 194-200 (cited in note 2). 
structure and forms of control stems from a very primitive view of governance as consisting primarily of formal law, and ignores the myriad ways in which private mechanisms serve to create self-regulating communities.

Let me illustrate how this central insight from law and society research might enrich organizational studies by drawing on recent work on the development of high-technology industries. In studies of the growth and development of Silicon Valley ${ }^{15}$ and of the origins of biotechnology, ${ }^{16}$ a critical role stands out for law firms as providers of transactional advice and as "Johnny Appleseeds" of corporate organization. Law firms have played a vital role in structuring high technology fields, in part by keeping their clients out of court and creating common understandings that facilitate exchange. In newly developing industries where no firms possess all the necessary skills to bring a product to market, collaboration across organizational boundaries becomes essential. But such reliance on competitors is fraught with risk and the possibility of exploitation. And this is precisely where a handful of law firms, with considerable expertise in the relevant industries (achieved through both experience and by hiring young staff with advanced degrees in molecular biology, materials science, and computer science), play a coordinating role in orchestrating relationships between parties so as to minimize risks and the possibilities of defection. Much of the dense collaborative structure of the biotechnology, computer, and software industries stems from the organizing role played by law and venture capital firms in creating a rich transactional infrastructure that links the industries and dampens litigiousness. In so doing, law firms have extended their role considerably beyond counselor to that of broker, dealmaker, proselytizer, therapist, consultant, and regulator. These industries have potent systems of governance; indeed, it is fair to say that their private orders are much more developed than public law. In the newly developing fields, intellectual property law is still primitive and rules for regulating new biotechnology medicines are in a nascent stage.

This illustrative case shows how law and society insights permit organizational researchers to treat the law in a more sophisticated manner, recognizing that forms of governance vary considerably and that there is ample opportunity to enhance our ability to explain differences across fields. In my view, stronger linkages between institutional analysis and legal scholarship are a most welcome development.

15. Mark C. Suchman, "On the Role of Law Firms in the Structuration of Silicon Valley" (Institute for Legal Studies Working Paper DPRP 11-7, University of Wisconsin Law School, 1994).

16. Walter W. Powell, "Inter-organizational Collaboration in the Biotechnology Industry," 152 J. Inst. \& Theoretical Econ. 197 (1996); Walter W. Powell, K. Koput, \& Laurel Smith-Doerr, "Interorganizational Collaboration and the Locus of Innovation: Networks of Learning in Biotechnology," 41 Admin. Sci. Q. 116 (1996). 